Supporting Information for:

\title{
Formation of a Ce(IV) Oxo Complex via Inner Sphere Nitrate Reduction
}

\author{
Peter L. Damon ${ }^{\dagger}$, Guang $\mathrm{Wu}^{\dagger}$, Nikolas Kaltsoyannis, ${ }^{\ddagger *}$ and Trevor W. Hayton ${ }^{\dagger *}$ \\ ${ }^{\dagger}$ Department of Chemistry and Biochemistry, University of California, Santa Barbara CA 93106 \\ $¥$ School of Chemistry, University of Manchester, Oxford Road, Manchester, M13 9PL, U.K.
}

*To whom correspondence should be addressed. Email: hayton@chem.ucsb.edu 


\section{Table of Contents}

$\begin{array}{ll}\text { Experimental Details } & \text { S3 }\end{array}$

$\begin{array}{ll}\text { NMR Spectra } & \text { S9 }\end{array}$

$\begin{array}{ll}\text { X-Ray Crystallographic Details } & \text { S23 }\end{array}$

$\begin{array}{ll}\text { X-Ray Structure of } 2 & \text { S24 }\end{array}$

$\begin{array}{ll}\text { Raman Spectra } & \text { S25 }\end{array}$

$\begin{array}{lr}\text { UV-Vis / NIR Spectra } & \text { S28 }\end{array}$

$\begin{array}{lr}\text { IR Spectra } & \text { S30 }\end{array}$

$\begin{array}{ll}\text { Computational Details } & \text { S33 }\end{array}$

$\begin{array}{lr}\text { Converged Cartesian coordinates and } & \text { S34 }\end{array}$

SCF energies

$\begin{array}{ll}\text { References } & \text { S41 }\end{array}$ 


\section{Experimental}

General Procedures. All reactions and subsequent manipulations were performed under anaerobic and anhydrous conditions in the glovebox or on the Schlenk line, under an atmosphere of dinitrogen. Pentane, hexanes, diethyl ether $\left(\mathrm{Et}_{2} \mathrm{O}\right)$, tetrahydrofuran (THF) and toluene were dried by passage over activated molecular sieves using a Vacuum Atmospheres solvent purification system. $\mathrm{C}_{6} \mathrm{D}_{6}$, hexamethyldisiloxane (HMDSO), benzene, 12-crown-4, cyclohexane, and tris(2-ethylamino)amine (TREN) were dried over activated $3 \AA$ molecular sieves for $24 \mathrm{~h}$ prior to use. $\mathrm{H}_{3} \mathrm{NN}_{3}$ and $\mathrm{Li}_{3}(\mathrm{THF})_{3}\left(\mathrm{NN}_{3}\right)\left(\mathrm{NN}_{3}{ }_{3}=\mathrm{N}\left(\mathrm{CH}_{2} \mathrm{CH}_{2} \mathrm{NR}\right)_{3}, \mathrm{R}=\mathrm{Si}^{\mathrm{t}} \mathrm{BuMe}_{2}\right)^{1}$ were prepared according to the literature procedures. $\mathrm{Ce}\left(\mathrm{NO}_{3}\right)_{3}(\mathrm{THF})_{4}$ was prepared by drying $\mathrm{Ce}\left(\mathrm{NO}_{3}\right)_{3}\left(\mathrm{H}_{2} \mathrm{O}\right)_{6}$ with trimethylorthoformate and recrystallizing from THF before use. ${ }^{2}$ All other reagents were purchased from commercial suppliers and used as received.

${ }^{1} \mathrm{H},{ }^{13} \mathrm{C}\left\{{ }^{1} \mathrm{H}\right\}$, and ${ }^{7} \mathrm{Li}\left\{{ }^{1} \mathrm{H}\right\}$ NMR spectra were recorded on an Agilent Technologies $400 \mathrm{MHz}$ 400-MR DD2 spectrometer. ${ }^{1} \mathrm{H}$ and ${ }^{13} \mathrm{C}\left\{{ }^{1} \mathrm{H}\right\}$ NMR spectra were referenced to external $\mathrm{SiMe}_{4}$ using residual protio solvent resonances as internal standards. ${ }^{7} \mathrm{Li}\left\{{ }^{1} \mathrm{H}\right\}$ NMR spectra were referenced indirectly with the ${ }^{1} \mathrm{H}$ chemical shift of $\mathrm{SiMe}_{4}$ at $0 \mathrm{ppm}$, according to IUPAC standard. ${ }^{3,4}$ IR spectra were recorded on a Nicolet 6700 FT-IR spectrometer. Electronic absorption spectra were recorded on a Shimadzu UV3600 UV-NIR Spectrometer. Elemental analyses were performed by the Microanalytical Laboratory at University of California (Berkeley, CA).

Raman Spectroscopy. Raman spectra were recorded on a LabRam Aramis microRaman system (Horiba Jobin Yvon) equipped with 1200 grooves/mm holographic gratings, and Peltier-cooled CCD camera. The $633 \mathrm{~nm}$ output of a Melles Griot He-Ne laser was used to excite the sample, 
and spectra were collected in a back scattering geometry using a confocal Raman Microscope (high stability BX40) equipped with Olympus objectives (MPlan 50x). Sample preparation was performed inside the glovebox: Pure crystalline solid samples were placed between a glass microscope slide and coverslip, sealed with a bead of silicone grease, and removed from the glovebox for spectral acquisition.

$\mathbf{H}_{3} \mathbf{N N}{ }_{3}$. This compound was prepared according to the published procedure. ${ }^{1} \mathrm{UV}$-vis NIR $\left(\mathrm{Et}_{2} \mathrm{O}, 0.10 \mathrm{mM}, 25^{\circ} \mathrm{C}, \mathrm{L} \cdot \mathrm{mol}^{-1} \cdot \mathrm{cm}^{-1}\right): 1183 \mathrm{~nm}(\varepsilon=490), 1234 \mathrm{~nm}(\varepsilon=370), 1391 \mathrm{~nm}(\varepsilon=$ $530), 1453 \mathrm{~nm}(\varepsilon=310)$.

Synthesis of [Li(12-crown-4)][(NN'$\left.\left.{ }_{3}\right) \operatorname{Ce}(\mathbf{O})\right]$ (1): A $20 \mathrm{~mL}$ scintillation vial was charged with $\mathrm{Ce}\left(\mathrm{NO}_{3}\right)_{3}(\mathrm{THF})_{4}(150 \mathrm{mg}, 0.244 \mathrm{mmol}), \mathrm{Li}_{3}(\mathrm{THF})_{3}\left(\mathrm{NN}_{3}\right)(174 \mathrm{mg}, 0.240 \mathrm{mmol})$, and a stir bar. To this mixture was added $\mathrm{Et}_{2} \mathrm{O}(4 \mathrm{~mL})$, which resulted in the formation of a pale yellow solution. This solution gradually darkened over time, becoming orange after $30 \mathrm{~min}$, whereupon 12-crown-4 (122 mg, $0.692 \mathrm{mmol})$, dissolved in $\mathrm{Et}_{2} \mathrm{O}(2 \mathrm{~mL})$, was added to the reaction mixture. This resulted in a color change from orange to yellow-orange. Stirring of the reaction mixture for $4 \mathrm{~d}$ resulted in a further color change to deep red-orange, concomitant with the deposition of a fine tan precipitate. This mixture was filtered through a Celite column supported on glass wool $(0.5 \mathrm{~cm} \times 2 \mathrm{~cm})$, to give a clear deep red filtrate. Hexanes $(5 \mathrm{~mL})$ was then added to the reaction mixture, which resulted in the deposition of a small amount of fine orange-brown precipitate. This solution was filtered through a Celite column supported on glass wool $(0.5 \mathrm{~cm} \times 2 \mathrm{~cm})$. The filtrate was then concentrated to ca. $3 \mathrm{~mL}$, and storage of this solution at $-25^{\circ} \mathrm{C}$ for $24 \mathrm{~h}$ resulted in the deposition of yellow blocks of $\mathbf{1}$, which were isolated by decanting the supernatant ( $72.0 \mathrm{mg}, 36 \%$ yield). X-ray quality crystals of $\mathbf{1}$ were grown by storage of a concentrated $\mathrm{C}_{6} \mathrm{H}_{12} / \mathrm{C}_{6} \mathrm{H}_{6}$ solution $(3: 1 \mathrm{v} / \mathrm{v})$ of $\mathbf{1}$ at $-25{ }^{\circ} \mathrm{C}$ for $24 \mathrm{~h} .{ }^{1} \mathrm{H}$ NMR $\left(\mathrm{C}_{6} \mathrm{D}_{6}, 25{ }^{\circ} \mathrm{C}, 400\right.$ 
MHz): $\delta 3.90$ (t, $\left.J_{\mathrm{HH}}=4.6 \mathrm{~Hz}, 6 \mathrm{H}, \mathrm{CH}_{2}\right), 3.07\left(\mathrm{br} \mathrm{s}, 8 \mathrm{H}, \mathrm{OCH}_{2}\right), 2.60\left(\mathrm{t}, J_{\mathrm{HH}}=4.4 \mathrm{~Hz}, 6 \mathrm{H}, \mathrm{CH}_{2}\right)$, 2.40 (br s, $\left.8 \mathrm{H}, \mathrm{OCH}_{2}\right), 1.41$ (s, 27H, $\left.\mathrm{C}\left(\mathrm{CH}_{3}\right)_{3}\right), 0.70$ (s, $\left.18 \mathrm{H}, \mathrm{Si}\left(\mathrm{CH}_{3}\right)_{2}\right) .{ }^{1} \mathrm{H}$ NMR (THF- $d_{8}, 25$ $\left.{ }^{\circ} \mathrm{C}, 400 \mathrm{MHz}\right): \delta 3.59\left(\mathrm{~s}, \mathrm{OCH}_{2}\right), 3.55\left(\mathrm{CH}_{2}\right), 2.39\left(\mathrm{t}, \mathrm{J}_{\mathrm{HH}}=4.5 \mathrm{~Hz}, 6 \mathrm{H}, \mathrm{CH}_{2}\right), 1.01(\mathrm{~s}, 27 \mathrm{H}$, $\left.\mathrm{C}\left(\mathrm{CH}_{3}\right)_{3}\right), 0.32\left(\mathrm{~s}, 18 \mathrm{H}, \mathrm{Si}\left(\mathrm{CH}_{3}\right)_{2}\right) \cdot{ }^{13} \mathrm{C}\left\{{ }^{1} \mathrm{H}\right\} \operatorname{NMR}\left(\mathrm{C}_{6} \mathrm{D}_{6}, 25^{\circ} \mathrm{C}, 100 \mathrm{MHz}\right): \delta 66.36\left(\mathrm{CH}_{2}\right), 64.36$ $\left(\mathrm{OCH}_{2}\right), 47.04\left(\mathrm{CH}_{2}\right), 28.48\left(\mathrm{C}\left(\mathrm{CH}_{3}\right)_{3}\right), 21.62\left(C\left(\mathrm{CH}_{3}\right)_{3}\right),-2.93\left(\mathrm{Si}\left(\mathrm{CH}_{3}\right)_{2}\right) .{ }^{7} \mathrm{Li}\left\{{ }^{1} \mathrm{H}\right\} \mathrm{NMR}$ $\left(\mathrm{C}_{6} \mathrm{D}_{6}, 25{ }^{\circ} \mathrm{C}, 155 \mathrm{MHz}\right): \delta-3.92(\mathrm{~s}) .{ }^{7} \mathrm{Li}\left\{{ }^{1} \mathrm{H}\right\}$ NMR (THF- $\left.d_{8}, 25{ }^{\circ} \mathrm{C}, 155 \mathrm{MHz}\right): \delta-3.68(\mathrm{~s})$. Anal. Calcd for $\mathrm{C}_{32} \mathrm{H}_{73} \mathrm{CeLiN}_{4} \mathrm{O}_{5} \mathrm{Si}_{3}: \mathrm{C}, 46.57 ; \mathrm{H}, 8.92 ; \mathrm{N}, 6.79$. Found: $\mathrm{C}, 46.74 ; \mathrm{H}, 8.96 ; \mathrm{N}$, 6.80. UV-vis $\left(\mathrm{Et}_{2} \mathrm{O}, 0.10 \mathrm{mM}, 25^{\circ} \mathrm{C}, \mathrm{L} \cdot \mathrm{mol}^{-1} \cdot \mathrm{cm}^{-1}\right): 912 \mathrm{~nm}(\varepsilon=270), 959 \mathrm{~nm}(\varepsilon=230), 1188$ $\mathrm{nm}(\varepsilon=190), 1242 \mathrm{~nm}(\varepsilon=1400), 1399 \mathrm{~nm}(\varepsilon=2100), 1440 \mathrm{~nm}(\varepsilon=1500)$. IR (KBr pellet, $\mathrm{cm}^{-1}$ ): 1470 (s), $1402(\mathrm{~m}), 1385$ (m), 1361 (w), 1335 (w), 1303 (w), 1287 (m), 1248 (s), $1137(\mathrm{~s})$, 1095 (s), 1059 (m), 1025 (s), 1006 (w), 933 (s), 826 (s), 806 (s), 766 (s), 722 (s), 696 (m), 652 (w), 547 (m), 439 (m). Raman (neat solid, $\mathrm{cm}^{-1}$ ): 1461 (vs), 1443 (vs), 1240 (w), 1206 (s), 1181 (w), $1090(w), 1057$ (w), $1026(w), 1003$ (s), 933 (s), 863 (s), 815 (s), 783 (v(Ce=O), s), 719 $(v(\mathrm{Ce}=\mathrm{O}), \mathrm{s}), 693(\mathrm{~s}), 568(\mathrm{vs}), 439(\mathrm{~s}), 366(\mathrm{w}), 218(\mathrm{w})$.

Synthesis of [Li(12-crown-4)][(NN' $\left.\left.{ }_{3}\right) \mathrm{Ce}\left(\kappa^{2}-\mathrm{O}_{2} \mathrm{NO}\right)\right]$ (2): To a stirring, colorless solution of $\mathrm{Ce}\left(\mathrm{NO}_{3}\right)_{3}(\mathrm{THF})_{4}(278 \mathrm{mg}, 0.452 \mathrm{mmol})$ in $\mathrm{THF}(5 \mathrm{~mL})$ was added $\mathrm{Li}_{3}(\mathrm{THF})_{3}\left(\mathrm{NN}_{3}{ }_{3}\right)(325 \mathrm{mg}$, $0.450 \mathrm{mmol}$ ). The reaction mixture quickly turned yellow-orange upon addition. After $30 \mathrm{~min}$ of stirring, a tan precipitate began to form. After $2 \mathrm{~h}$ of stirring, the orange solution was filtered through a Celite column supported on glass wool $(0.5 \mathrm{~cm} \times 2 \mathrm{~cm})$. 12-crown-4 $(80 \mu \mathrm{L}, 0.49$ mmol) was then added to the orange filtrate, which resulted in the deposition of a white powder. The volatiles were then removed in vacuo to give an orange-red oil. This material was triturated with pentane $(2 \mathrm{~mL})$ to give a tacky orange solid. The solid was then dissolved in $\mathrm{Et}_{2} \mathrm{O}(5 \mathrm{~mL})$ and the resulting solution was filtered through a Celite column supported on glass wool $(0.5 \mathrm{~cm}$ 
$\times 2 \mathrm{~cm}$ ) to give a clear orange filtrate, while leaving a tacky white precipitate on the Celite. The filtrate was concentrated to ca. $3 \mathrm{~mL}$, and layered with hexanes $(5 \mathrm{~mL})$. Storage of this solution at $-25^{\circ} \mathrm{C}$ for $24 \mathrm{~h}$ resulted in the deposition of orange needles of $\mathbf{2}$, which were isolated by decanting the supernatant ( $163 \mathrm{mg}, 41 \%$ yield). Concentration of the supernatant and further storage at $-25{ }^{\circ} \mathrm{C}$ for several days results in the deposition of another batch of orange needles ( 23 mg, Total yield: $47 \%$ ). X-ray quality crystals of 2 were obtained from a toluene solution layered with hexanes. ${ }^{1} \mathrm{H}$ NMR $\left(\mathrm{C}_{6} \mathrm{D}_{6}, 25^{\circ} \mathrm{C}, 400 \mathrm{MHz}\right): \delta 3.68\left(\mathrm{~s}, 27 \mathrm{H}, \mathrm{C}\left(\mathrm{CH}_{3}\right)_{3}\right), 2.97\left(\mathrm{~s}, 6 \mathrm{H}, \mathrm{CH}_{2}\right)$, $1.68\left(\mathrm{~s}, 16 \mathrm{H}, \mathrm{OCH}_{2}\right),-0.85\left(\mathrm{~s}, 18 \mathrm{H}, \mathrm{Si}\left(\mathrm{CH}_{3}\right)_{2}\right),-6.62\left(\mathrm{~s}, 6 \mathrm{H}, \mathrm{CH}_{2}\right) .{ }^{7} \mathrm{Li}\left\{{ }^{1} \mathrm{H}\right\} \mathrm{NMR}\left(\mathrm{C}_{6} \mathrm{D}_{6}, 25{ }^{\circ} \mathrm{C}\right.$, $155 \mathrm{MHz}$ ): $\delta-2.28$ (s). ${ }^{1} \mathrm{H}$ NMR (THF-d $\left.d_{8}, 25^{\circ} \mathrm{C}, 400 \mathrm{MHz}\right): \delta 3.54$ (s, 16H, $\mathrm{OCH}_{2}$ ), $2.81(\mathrm{~s}, 6 \mathrm{H}$, $\left.\mathrm{CH}_{2}\right), 2.72\left(\mathrm{~s}, 27 \mathrm{H}, \mathrm{C}\left(\mathrm{CH}_{3}\right)_{3}\right),-1.15\left(\mathrm{~s}, 18 \mathrm{H}, \mathrm{Si}\left(\mathrm{CH}_{3}\right)_{2}\right),-4.59$ (s, 6H, $\left.\mathrm{CH}_{2}\right) .{ }^{7} \mathrm{Li}\left\{{ }^{1} \mathrm{H}\right\} \mathrm{NMR}$ (THF- $d_{8}, 25^{\circ} \mathrm{C}, 155 \mathrm{MHz}$ ): $\delta-0.26$ (br s). Anal. Calcd for $\mathrm{CeC}_{32} \mathrm{H}_{73} \mathrm{~N}_{5} \mathrm{O}_{7} \mathrm{Si}_{3} \mathrm{Li}$ : C, 44.11; H, 8.45; $\mathrm{N}, 8.04$. Found: $\mathrm{C}, 44.49 ; \mathrm{H}, 8.34 ; \mathrm{N}, 7.67$. UV-vis $\left(\mathrm{Et}_{2} \mathrm{O}, 0.10 \mathrm{mM}, 25^{\circ} \mathrm{C}, \mathrm{L} \cdot \mathrm{mol}^{-1} \cdot \mathrm{cm}^{-1}\right)$ : $444 \mathrm{~nm}(\varepsilon=470), 1210 \mathrm{~nm}(\varepsilon=800), 1410 \mathrm{~nm}(\varepsilon=580), 1450 \mathrm{~nm}(\varepsilon=400)$. IR (KBr pellet, $\left.\mathrm{cm}^{-1}\right): 1640((v(\mathrm{~N}-\mathrm{O}), \mathrm{sh} w), 1620(\mathrm{v}(\mathrm{N}-\mathrm{O}), \mathrm{m}) 1471(\mathrm{~s}), 1463(\mathrm{~s}), 1403(\mathrm{~s}), 1385(\mathrm{~s}), 1362(\mathrm{~s})$, $1321(\mathrm{~m}), 1302$ (m), 1288 (m), 1248 (s), 1201 (w), 1133 (s), 1093 (s), 1061 (w), 1023 (m), 980 (w), 933 (s), $825(\mathrm{~s}), 808$ (s), 767 (m), $719(\mathrm{w}), 659$ (w), 554 (w), 436 (w), 408 (w). Raman (neat solid, $\mathrm{cm}^{-1}$ ): 1558 (v(N-O) vs), 1470 (vs), 1450 (vs), 1269 (w), 1212 (w), 1034 (vw), 939 (s), $919(\mathrm{~s}), 843(\mathrm{w}), 821(\mathrm{~s}), 653(\mathrm{w}), 576(\mathrm{vs}), 422(\mathrm{~s}), 368(\mathrm{w}), 318(\mathrm{w}), 220(\mathrm{w})$.

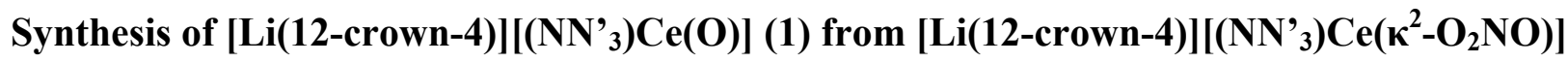

(2): A $20 \mathrm{~mL}$ scintillation vial was charged with complex 2 (163 $\mathrm{mg}, 0.187 \mathrm{mmol})$, a stir bar, and $\mathrm{Et}_{2} \mathrm{O}(4 \mathrm{~mL})$ to give a clear orange solution. Storage of this solution at room temperature in a glove box for $3 \mathrm{~d}$ resulting in a color change from orange to orange-red, concomitant with the deposition of a fine tan precipitate. This mixture was filtered through a Celite column supported 
on glass wool $(0.5 \mathrm{~cm} \times 2 \mathrm{~cm})$ to give a clear orange red filtrate. Hexanes $(10 \mathrm{~mL})$ was then added to the solution and subsequent storage of this solution at $-25^{\circ} \mathrm{C}$ for $30 \mathrm{~min}$ result in the deposition of a fine orange-brown precipitate. This mixture was then filtered through a Celite column supported on glass wool $(0.5 \mathrm{~cm} \times 2 \mathrm{~cm})$ to give a clear orange red filtrate. The filtrate was concentrated in vacuo to ca. $5 \mathrm{~mL}$, and storage of this solution at $-25{ }^{\circ} \mathrm{C}$ for $24 \mathrm{~h}$ resulted in the deposition of yellow crystals of $\mathbf{1}$, which were isolated by decanting the supernatant (66 mg, $43 \%$ yield). The ${ }^{1} \mathrm{H}$ NMR spectrum of the isolated product was consistent with that recorded for authentic material.

Synthesis of $\left(\mathbf{N N}^{{ }_{3}}\right) \mathbf{C e}\left(\mathrm{OSiMe}_{2}{ }^{\mathbf{t}} \mathbf{B u}\right)(\mathbf{3})$ : To a stirring, yellow solution of $\mathbf{1}(65.5 \mathrm{mg}, 0.079$ mmol) in THF (2 mL), was added ${ }^{t} \mathrm{BuMe}_{2} \mathrm{SiCl}(13.8 \mathrm{mg}, 0.092 \mathrm{mmol})$ as a colorless THF (2 mL) solution. After $30 \mathrm{~min}$ of stirring, the volatiles were removed in vacuo. The resulting red oil was triturated with pentane $(2 \mathrm{~mL})$ to give a tacky red solid. The solid was then dissolved in pentane $(5 \mathrm{~mL})$ and the resulting solution was filtered through a Celite column supported on glass wool $(0.5 \mathrm{~cm} \times 2 \mathrm{~cm})$ to give a clear red filtrate, while leaving a tacky white precipitate on the Celite. The volatiles were then removed in vacuo to give a red crystalline solid. This material was dissolved in HMDSO $(5 \mathrm{~mL})$, and the resulting red solution was filtered through a Celite column supported on glass wool $(0.5 \mathrm{~cm} \times 2 \mathrm{~cm})$ to give a clear red filtrate. The filtrate was concentrated in vacuo to ca. $1 \mathrm{~mL}$ and storage of this solution at $-25^{\circ} \mathrm{C}$ for $24 \mathrm{~h}$ resulted in the deposition of red crystals, which were isolated by decanting the supernatant $(19.0 \mathrm{mg}, 32 \%$ yield). Anal. Calcd for $\mathrm{C}_{30} \mathrm{H}_{72} \mathrm{CeN}_{4} \mathrm{OSi}_{4}$ : C, 47.58; H, 9.58; N, 7.40. Found: C, 47.58; H, 9.71; $\mathrm{N}, 7.42 .{ }^{1} \mathrm{H}$ NMR $\left(\mathrm{C}_{6} \mathrm{D}_{6}, 25{ }^{\circ} \mathrm{C}, 400 \mathrm{MHz}\right): \delta 4.32\left(\mathrm{t}, J_{\mathrm{HH}}=4.4 \mathrm{~Hz}, 6 \mathrm{H}, \mathrm{CH}_{2}\right), 2.87\left(\mathrm{t}, J_{\mathrm{HH}}=4.2\right.$ $\left.\mathrm{Hz}, 6 \mathrm{H}, \mathrm{CH}_{2}\right), 1.21\left(\mathrm{~s}, 9 \mathrm{H}, \mathrm{C}\left(\mathrm{CH}_{3}\right)_{3}\right), 1.02\left(\mathrm{~s}, 27 \mathrm{H}, \mathrm{C}\left(\mathrm{CH}_{3}\right)_{3}\right), 0.42\left(\mathrm{~s}, 6 \mathrm{H}, \mathrm{Si}\left(\mathrm{CH}_{3}\right)_{2}\right), 0.34$ (s, $\left.18 \mathrm{H}, \mathrm{Si}\left(\mathrm{CH}_{3}\right)_{2}\right) .{ }^{13} \mathrm{C}\left\{{ }^{1} \mathrm{H}\right\} \operatorname{NMR}\left(\mathrm{C}_{6} \mathrm{D}_{6}, 25{ }^{\circ} \mathrm{C}, 100 \mathrm{MHz}\right): \delta 67.68\left(\mathrm{CH}_{2}\right), 49.12\left(\mathrm{CH}_{2}\right), 27.90$ 
$\left(\mathrm{C}\left(\mathrm{CH}_{3}\right)_{3}\right), 27.75\left(\mathrm{C}\left(\mathrm{CH}_{3}\right)_{3}\right), 21.11\left(\mathrm{C}\left(\mathrm{CH}_{3}\right)_{3}\right), 20.55\left(C\left(\mathrm{CH}_{3}\right)_{3}\right), 0.27\left(\mathrm{Si}\left(\mathrm{CH}_{3}\right)_{2}\right),-4.20$

$\left(\mathrm{Si}\left(\mathrm{CH}_{3}\right)_{2}\right) . \mathrm{UV}$-vis $\left(\mathrm{Et}_{2} \mathrm{O}, 0.10 \mathrm{mM}, 25^{\circ} \mathrm{C}, \mathrm{L} \cdot \mathrm{mol}^{-1} \cdot \mathrm{cm}^{-1}\right): 478 \mathrm{~nm}(\varepsilon=2400), 912 \mathrm{~nm}(\varepsilon=$ 300), $965 \mathrm{~nm}(\varepsilon=260), 1026 \mathrm{~nm}(\varepsilon=250), 1189 \mathrm{~nm}(\varepsilon=1400), 1229 \mathrm{~nm}(\varepsilon=1000), 1405 \mathrm{~nm}$ $(\varepsilon=1300), 1448 \mathrm{~nm}(\varepsilon=1000)$. IR (KBr pellet, $\left.\mathrm{cm}^{-1}\right): 1470(\mathrm{vs}), 1463(\mathrm{~s}), 1445(\mathrm{w}), 1406(\mathrm{w})$ 1386 (vw), 1358 (w), 1333 (vw), 1270 (s), 1249 (vs), 1146 (vw), 1110 (vw), 1073 (vs), 1058 (s), 1029 (w), 1005 (w), 925 (vs), 895 (vs), 828 (vs), 800 (vs), 783 (vs), 771 (vs), 737 (w), 706 (vs), $672(\mathrm{w}), 659$ (s), $556(\mathrm{w}), 455$ (s), 435 (w), 416 (w). Raman (neat solid, $\mathrm{cm}^{-1}$ ): 1467(vs), 1448(vs), 1212(s), 1185(vw), 1008(w), 939(s), 835(s), 666(s), 578(vs), 447(vw), 398(vw), 349(vw), 200(w).

X-ray Crystallography. Data for $\mathbf{1}$ - $\mathbf{3}$ were collected on a Bruker KAPPA APEX II diffractometer equipped with an APEX II CCD detector using a TRIUMPH monochromater with a Mo K $\alpha$ X-ray source $(\alpha=0.71073 \AA)$. The crystals of $\mathbf{1}$ - $\mathbf{3}$ were mounted on a cryoloop under Paratone-N oil, and all data were collected at 100(2) K using an Oxford nitrogen gas cryostream system. X-ray data for 1, 2, and $\mathbf{3}$ were collected utilizing frame exposures of 5, 20, and 10 seconds, respectively. Data collection and cell parameter determination were conducted using the SMART program. ${ }^{5}$ Integration of the data frames and final cell parameter refinement were performed using SAINT software. ${ }^{6}$ Absorption corrections of the data for $\mathbf{1}$ - $\mathbf{3}$ were carried out using the multi-scan method SADABS. ${ }^{7}$ Subsequent calculations were carried out using SHELXTL. ${ }^{8}$ Structure determination was done using direct or Patterson methods and difference Fourier techniques. All hydrogen atom positions were idealized, and rode on the atom of attachment. Structure solution, refinement, graphics, and creation of publication materials were performed using SHELXTL. ${ }^{8}$ Idealized hydrogen atoms were not assigned to disordered carbon atoms. Further crystallographic details for complexes $\mathbf{1}$ - $\mathbf{3}$ can be found in Table S1. 


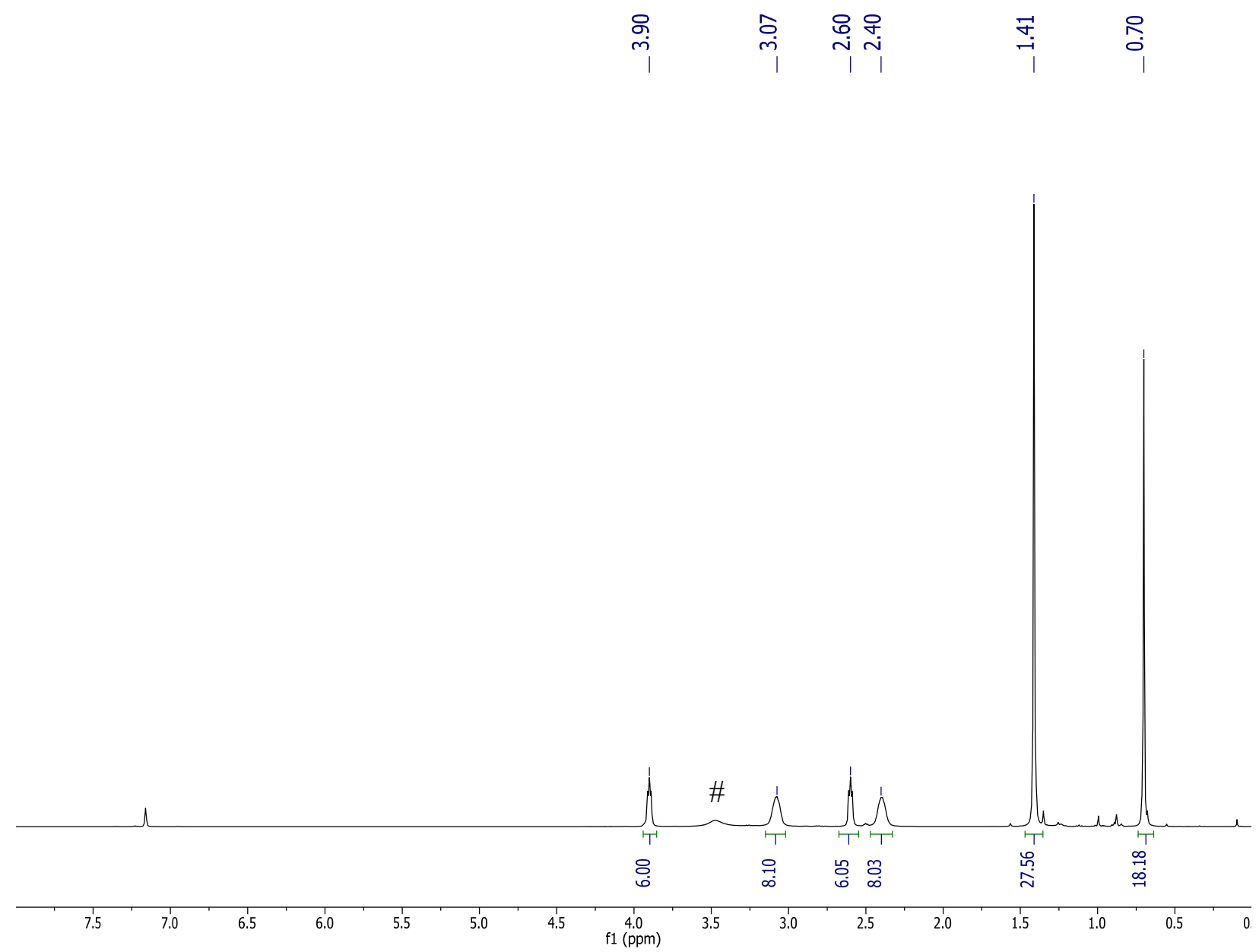

Figure S1: ${ }^{1} \mathrm{H}$ NMR spectrum of $\left[\mathrm{Li}(12\right.$-crown-4) $]\left[\left(\mathrm{NN}^{\prime}{ }_{3}\right) \mathrm{Ce}(\mathrm{O})\right](\mathbf{1})$ in $\mathrm{C}_{6} \mathrm{D}_{6}$. \# indicates the presence of free 12-crown-4. 


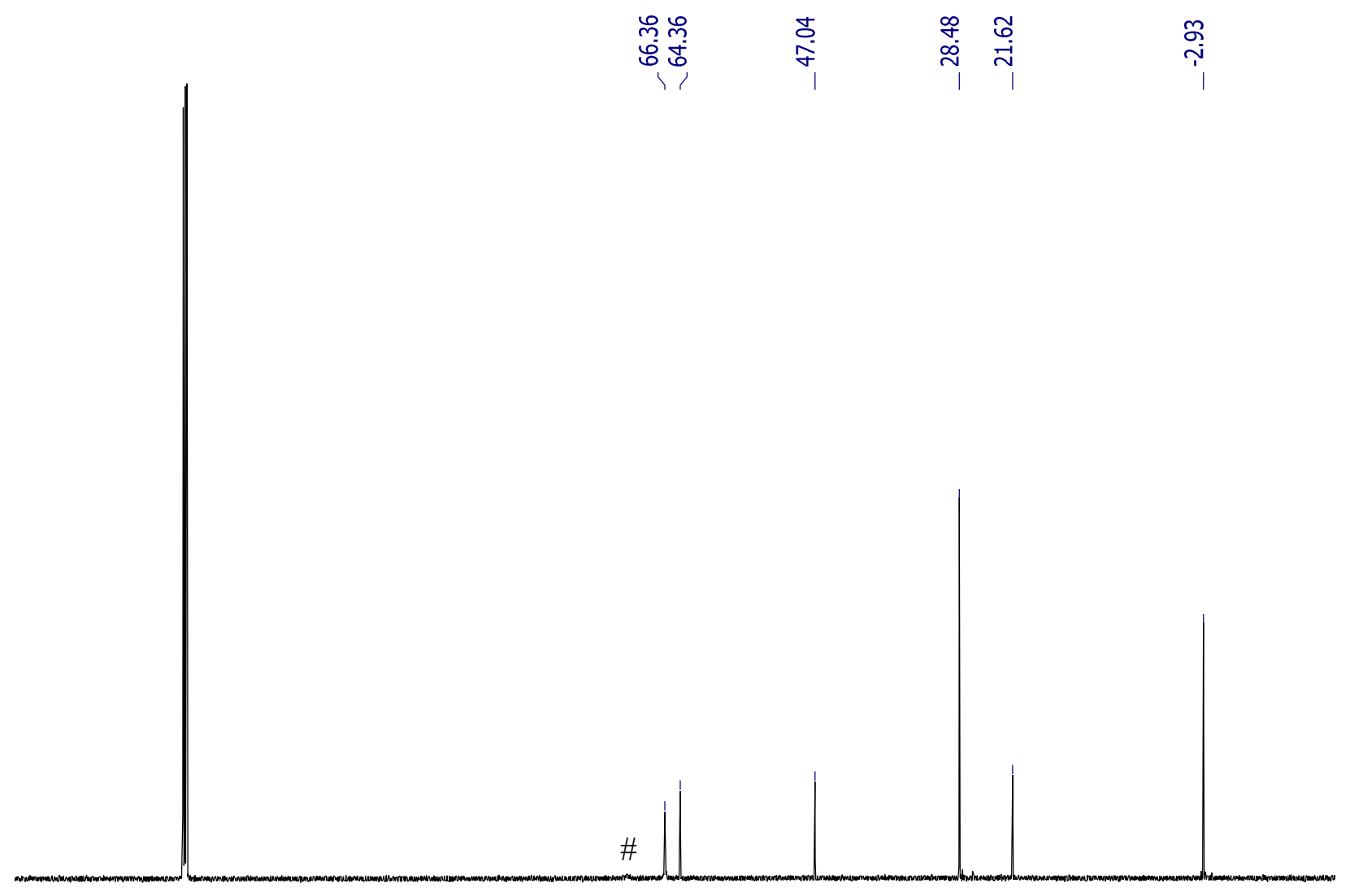

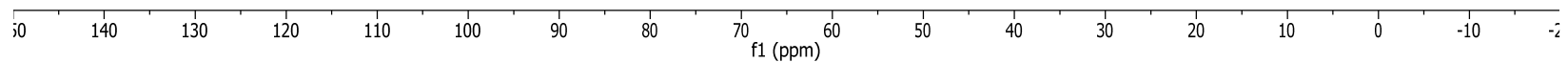

Figure S2: ${ }^{13} \mathrm{C}\left\{{ }^{1} \mathrm{H}\right\}$ NMR spectrum of $\left[\mathrm{Li}(12\right.$-crown-4) $]\left[\left(\mathrm{NN}_{3}\right) \mathrm{Ce}(\mathrm{O})\right](\mathbf{1})$ in $\mathrm{C}_{6} \mathrm{D}_{6}$. \# indicates the presence of free 12-crown-4. 


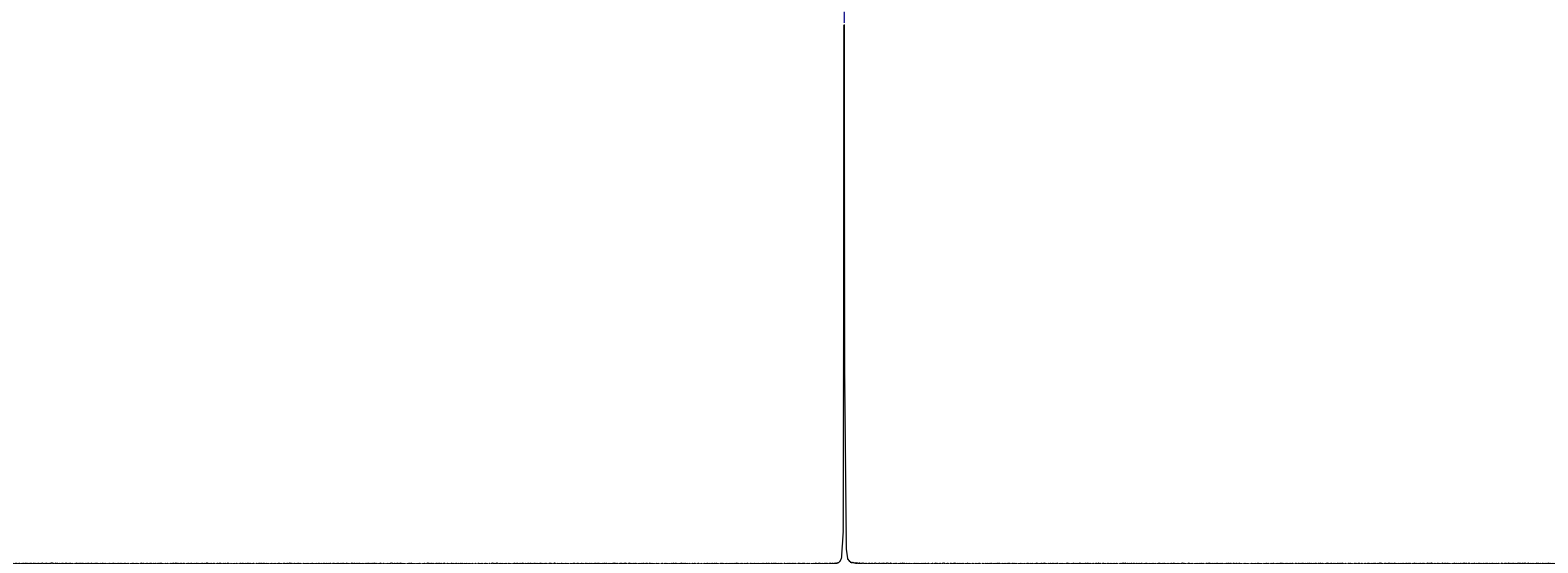

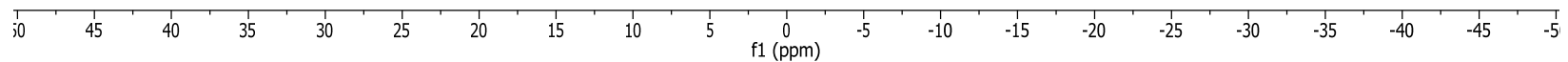

Figure S3: ${ }^{7} \mathrm{Li}\left\{{ }^{1} \mathrm{H}\right\}$ NMR spectrum of $\left[\mathrm{Li}\left(12\right.\right.$-crown-4)][(NN'$\left.\left.{ }_{3}\right) \mathrm{Ce}(\mathrm{O})\right](\mathbf{1})$ in $\mathrm{C}_{6} \mathrm{D}_{6}$. 


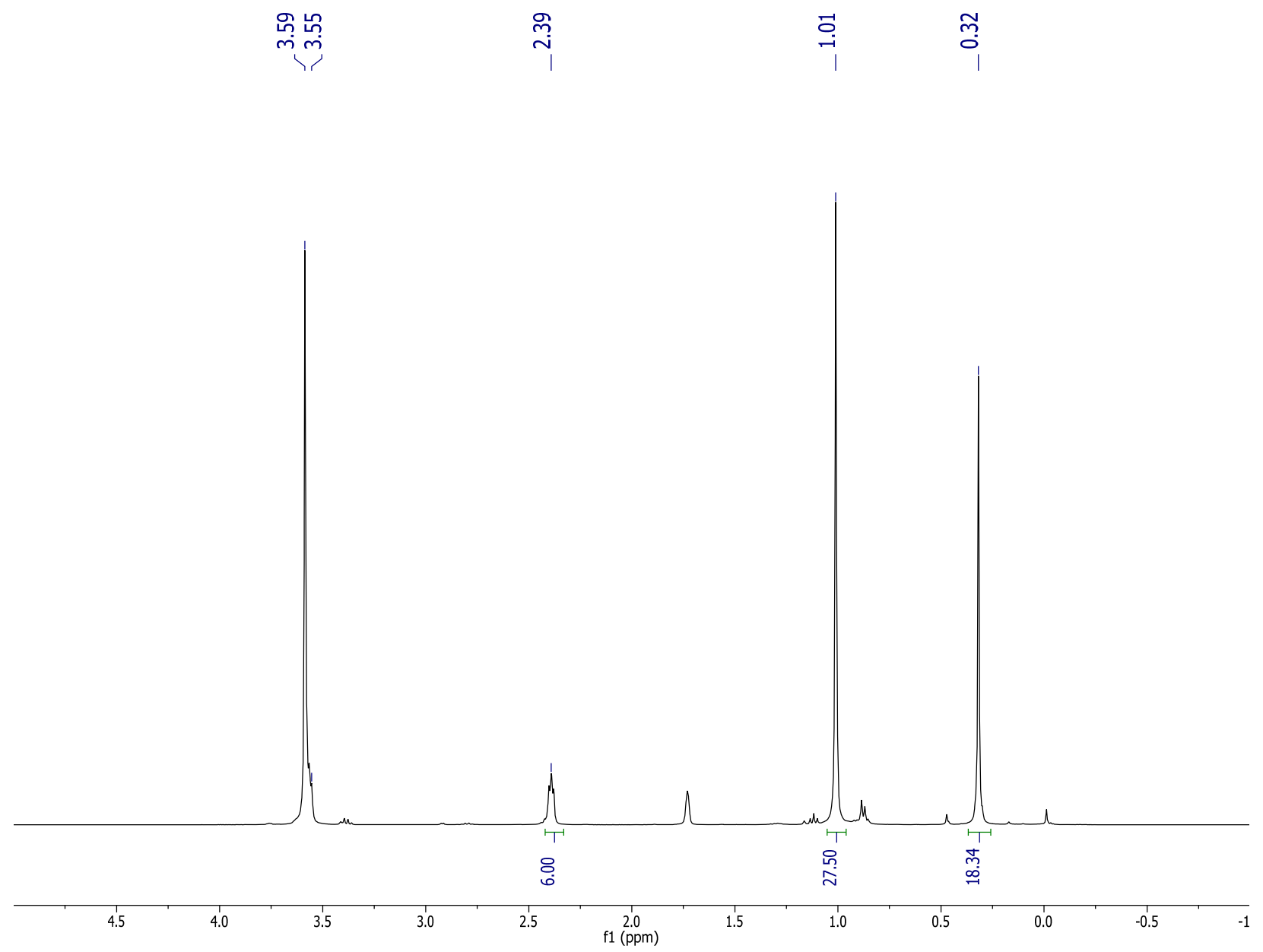

Figure S4: ${ }^{1} \mathrm{H}$ NMR spectrum of $\left[\mathrm{Li}\left(12\right.\right.$-crown-4)][(NN'$\left.\left.{ }_{3}\right) \mathrm{Ce}(\mathrm{O})\right](\mathbf{1})$ in $\mathrm{THF}-\mathrm{d}_{8}$. 


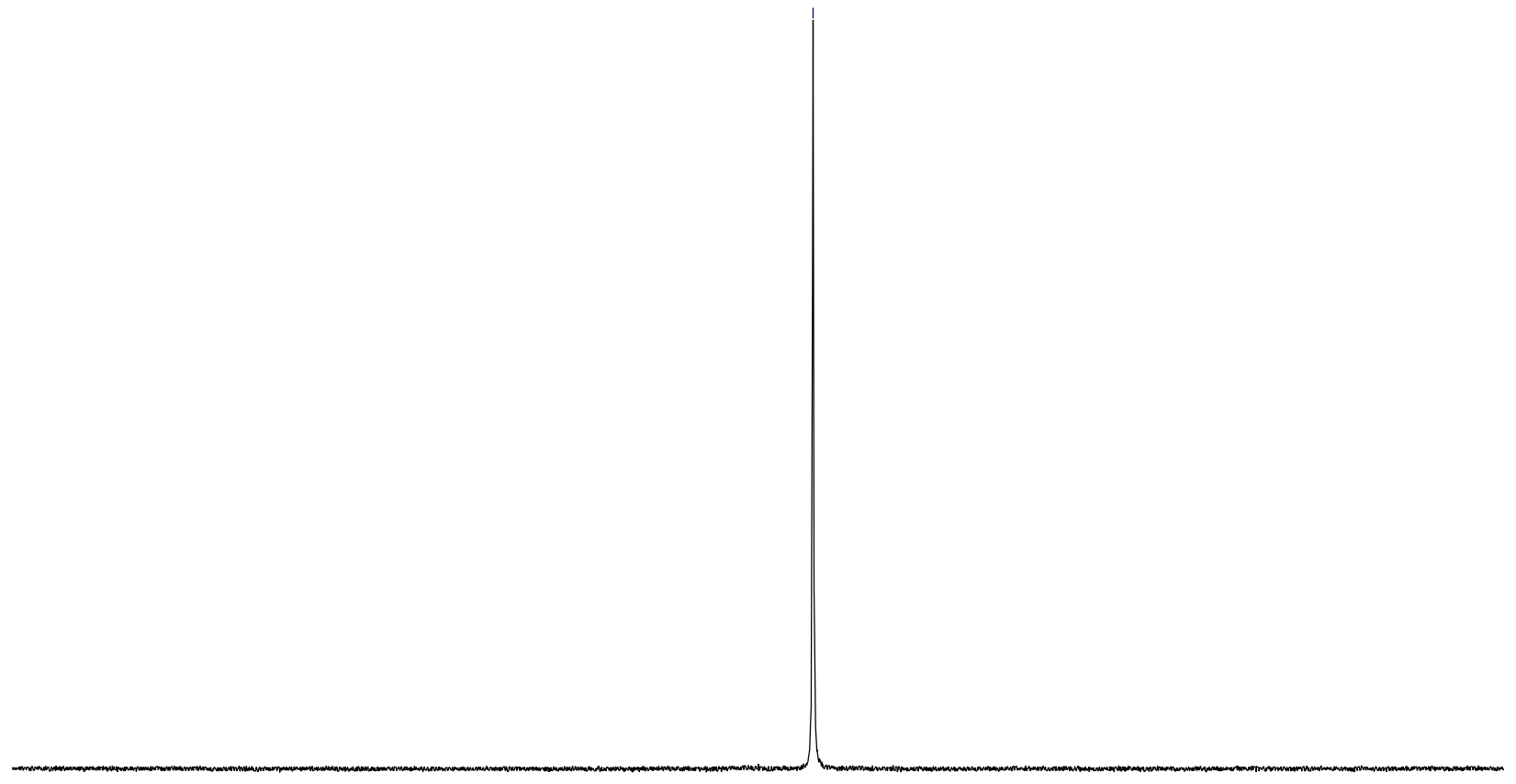

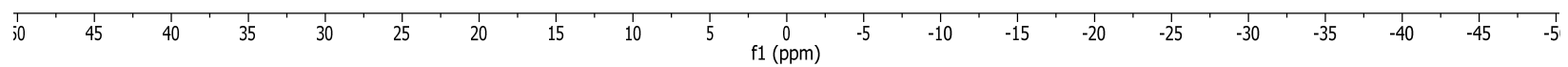

Figure S5: ${ }^{7} \mathrm{Li}\left\{{ }^{1} \mathrm{H}\right\}$ NMR spectrum of $\left[\mathrm{Li}(12-\right.$ crown-4) $]\left[\left(\mathrm{NN}_{3}\right) \mathrm{Ce}(\mathrm{O})\right](\mathbf{1})$ in $\mathrm{THF}-d_{8}$. 


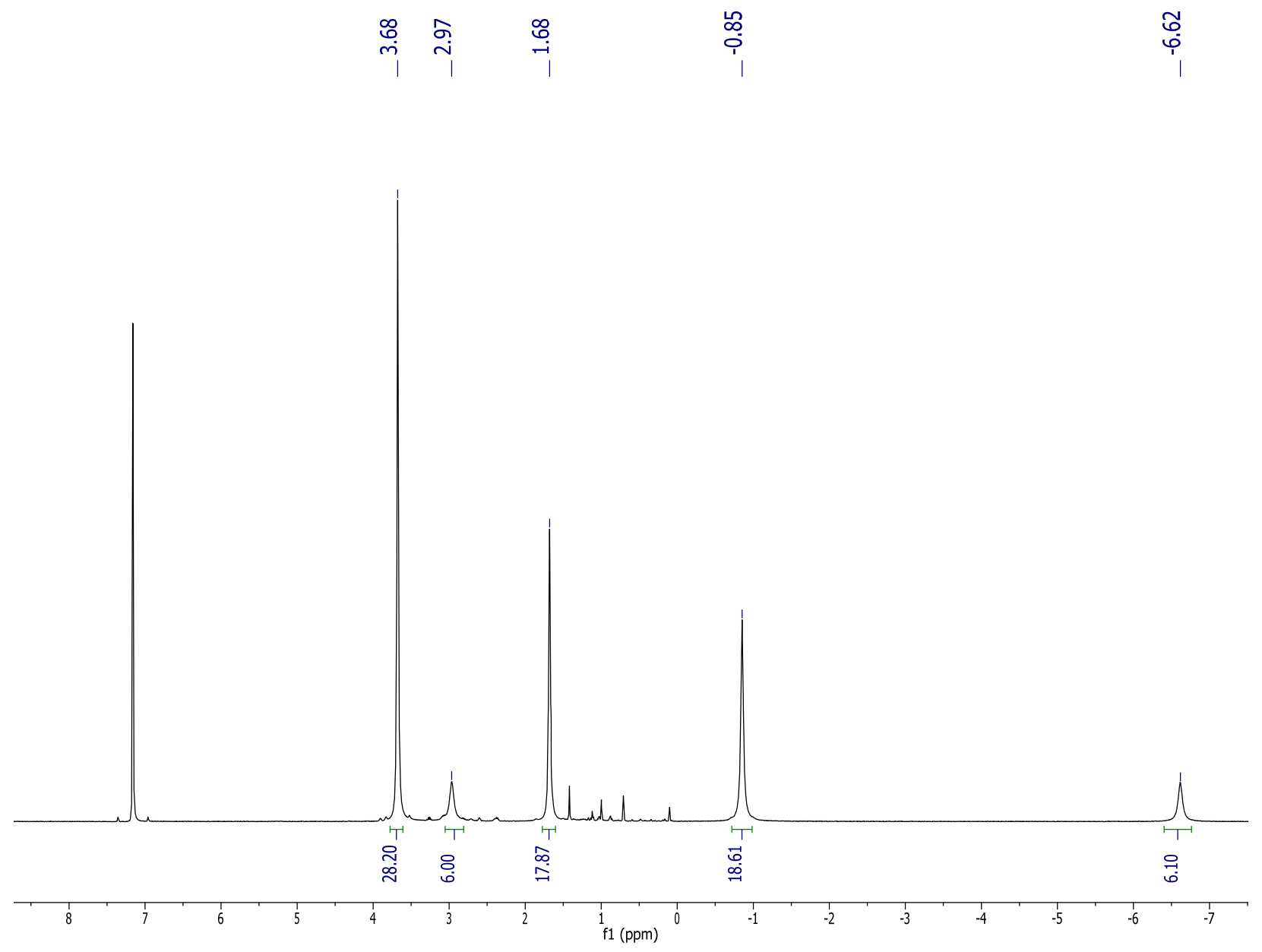

Figure S6: ${ }^{1} \mathrm{H}$ NMR spectrum of $\left[\mathrm{Li}(12\right.$-crown-4) $]\left[\left(\mathrm{NN}^{\prime}{ }_{3}\right) \mathrm{Ce}\left(\mathrm{K}^{2}-\mathrm{O}_{2} \mathrm{NO}\right)\right](2)$ in $\mathrm{C}_{6} \mathrm{D}_{6}$. 


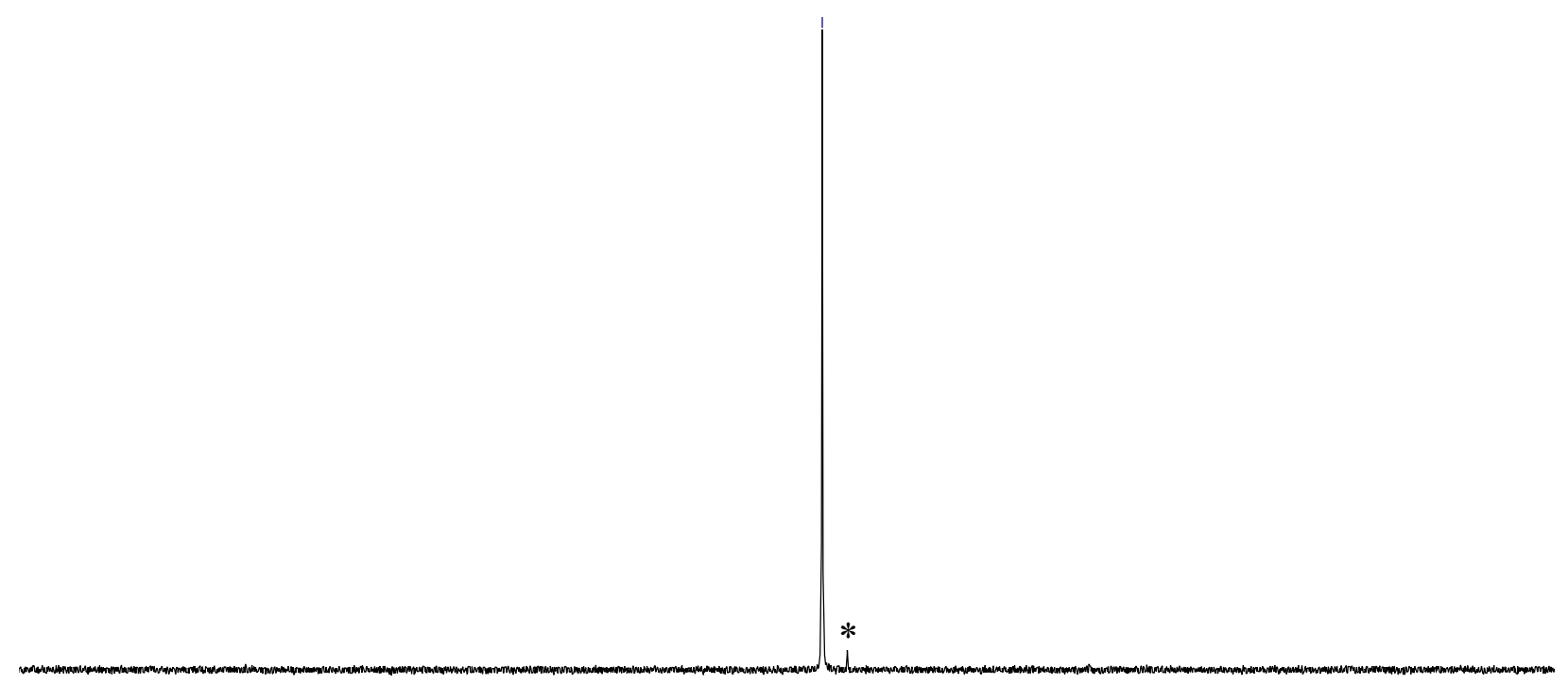

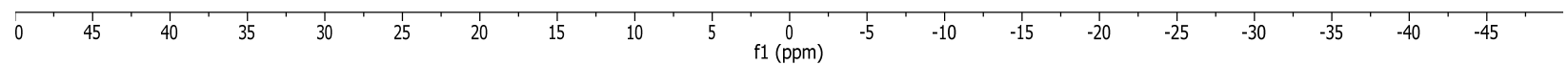

Figure S7: ${ }^{7} \mathrm{Li}\left\{{ }^{1} \mathrm{H}\right\}$ NMR spectrum of $\left[\mathrm{Li}\left(12\right.\right.$-crown-4)][(NN'$\left.\left.{ }_{3}\right) \mathrm{Ce}\left(\mathrm{k}^{2}-\mathrm{O}_{2} \mathrm{NO}\right)\right](2)$ in $\mathrm{C}_{6} \mathrm{D}_{6}$. * indicates the formation of a small amount of complex $\mathbf{1}$. 


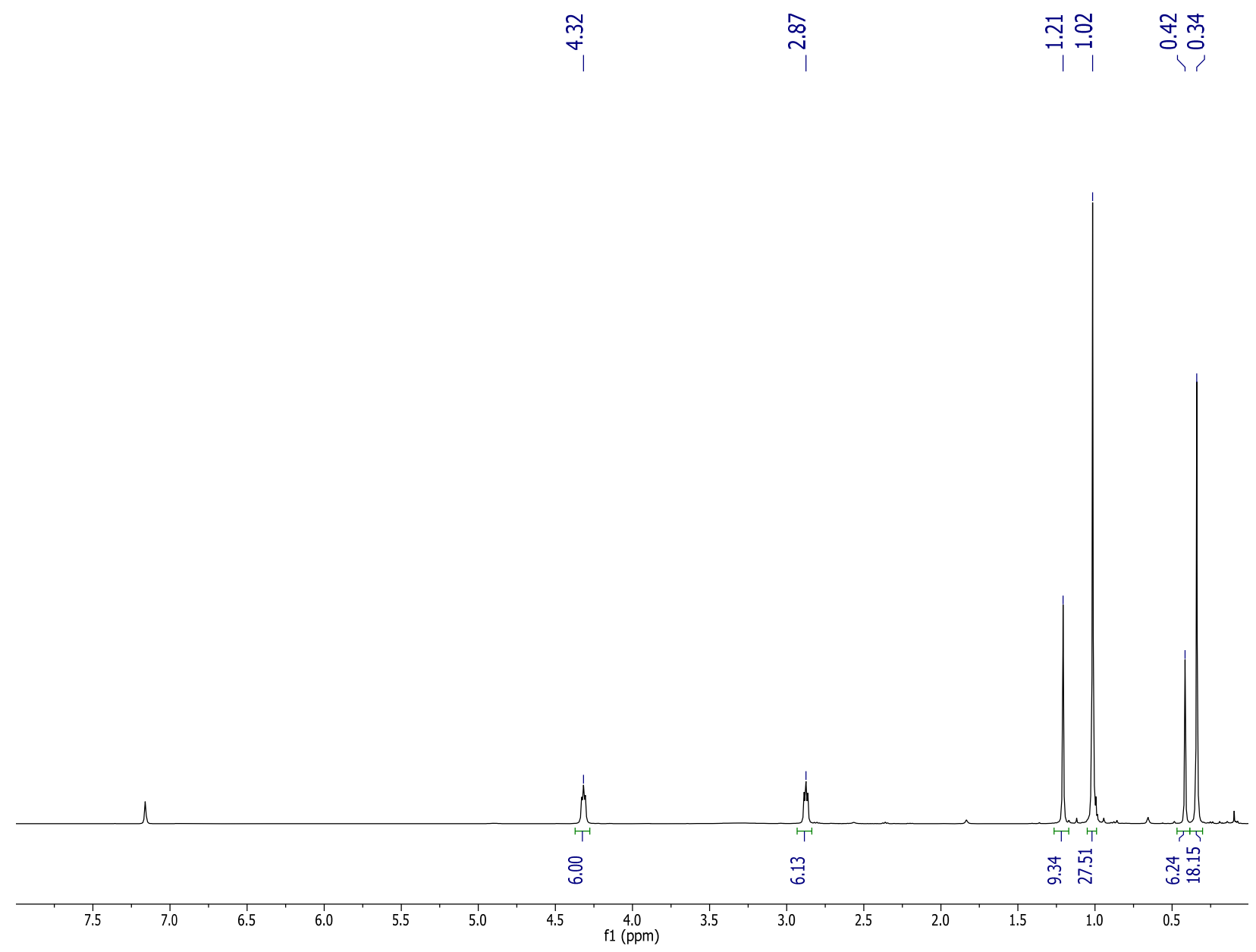

Figure S8: ${ }^{1} \mathrm{H}$ NMR spectrum of $\left(\mathrm{NN}_{3}{ }_{3}\right) \mathrm{Ce}\left(\mathrm{OSiMe}_{2}{ }^{\mathrm{t}} \mathrm{Bu}\right)(3)$ in $\mathrm{C}_{6} \mathrm{D}_{6}$. 


\begin{tabular}{|c|c|c|c|c|}
\hline & 굼 & 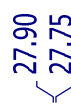 & 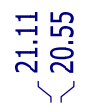 & \\
\hline
\end{tabular}

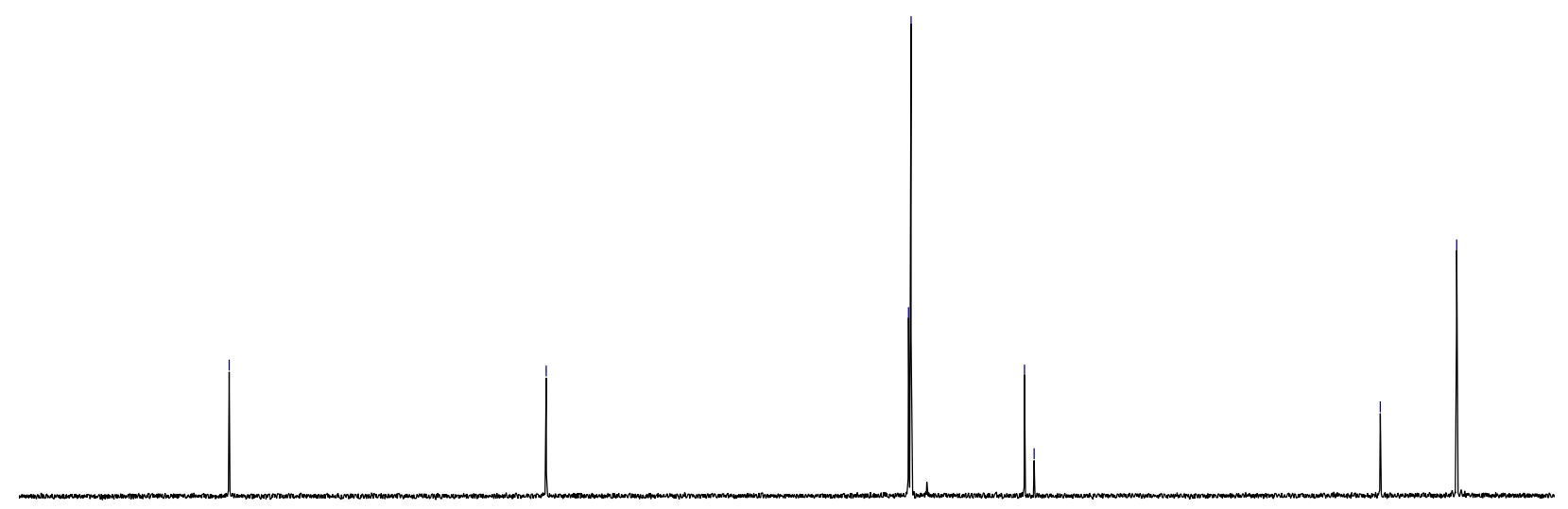

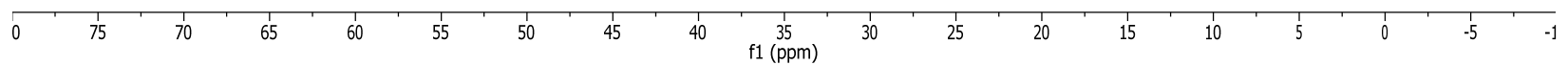

Figure S9: ${ }^{13} \mathrm{C}\left\{{ }^{1} \mathrm{H}\right\}$ NMR spectrum of $\left(\mathrm{NN}_{3}\right) \mathrm{Ce}\left(\mathrm{OSiMe}_{2}{ }^{\mathrm{t}} \mathrm{Bu}\right)(3)$ in $\mathrm{C}_{6} \mathrm{D}_{6}$. 


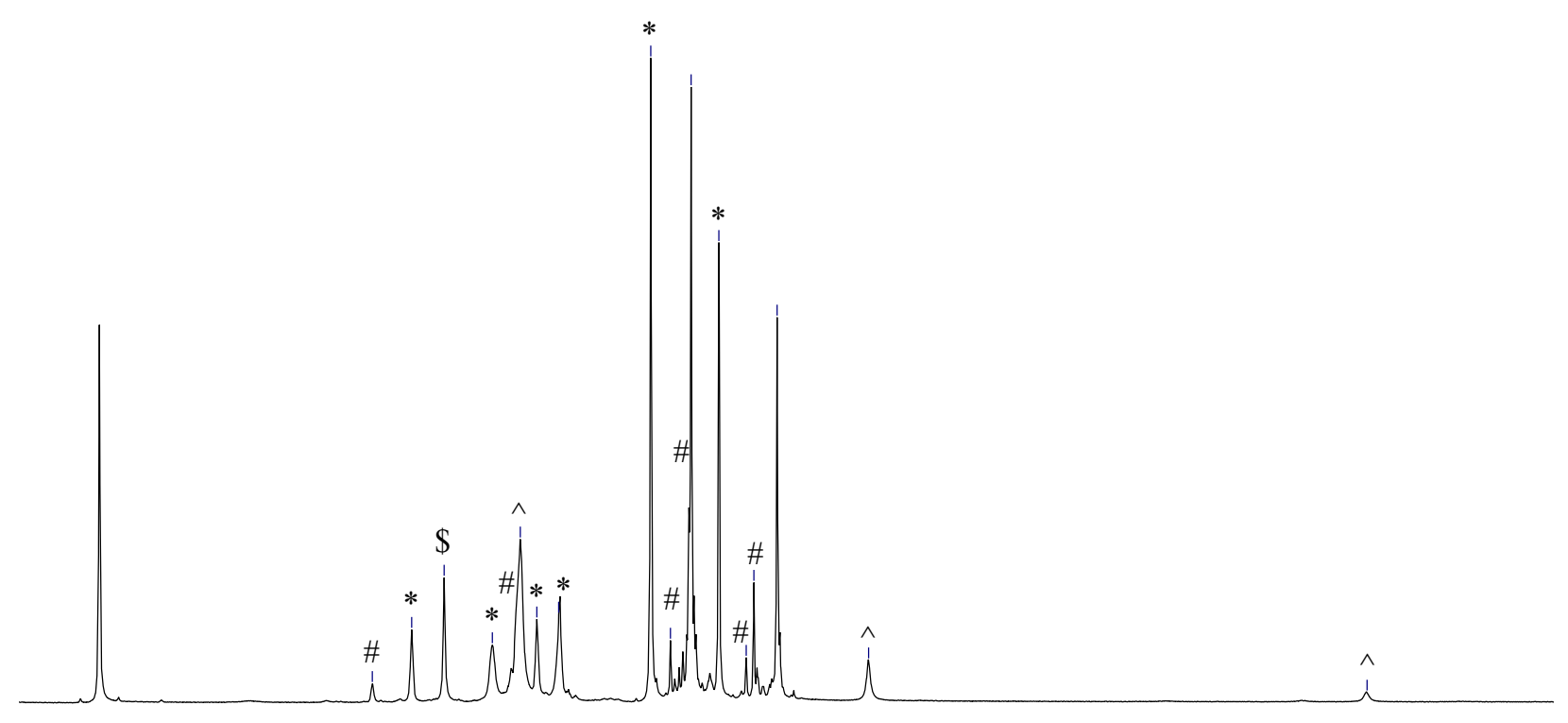

Figure S10: ${ }^{1} \mathrm{H}$ NMR spectrum $\left(\right.$ in $\mathrm{C}_{6} \mathrm{D}_{6}$ ) of an aliquot of the reaction to form $\mathbf{1}$ from $\mathbf{2}$. * indicates the presence of $\mathbf{1}, \#$ indicates the presence of $\mathbf{3}, \wedge$ indicates the presence of $\mathbf{2}$, and $\$$ indicates the presence of free 12-crown-4. Experimental Details: A yellow-orange $\mathrm{Et}_{2} \mathrm{O}(4 \mathrm{~mL})$ solution of complex 2 (58 mg, $0.067 \mathrm{mmol})$ was allowed to stir at room temperature in the glove box. After $48 \mathrm{~h}$, an aliquot of the reaction mixture was transferred to a $20 \mathrm{~mL}$ scintillation vial and the volatiles were removed in vacuo to give an orange oil. This material was then dissolved in $\mathrm{C}_{6} \mathrm{D}_{6}(0.5 \mathrm{~mL})$ and ${ }^{1} \mathrm{H}$ and ${ }^{7} \mathrm{Li}\left\{{ }^{1} \mathrm{H}\right\} \mathrm{NMR}$ spectra were recorded. 


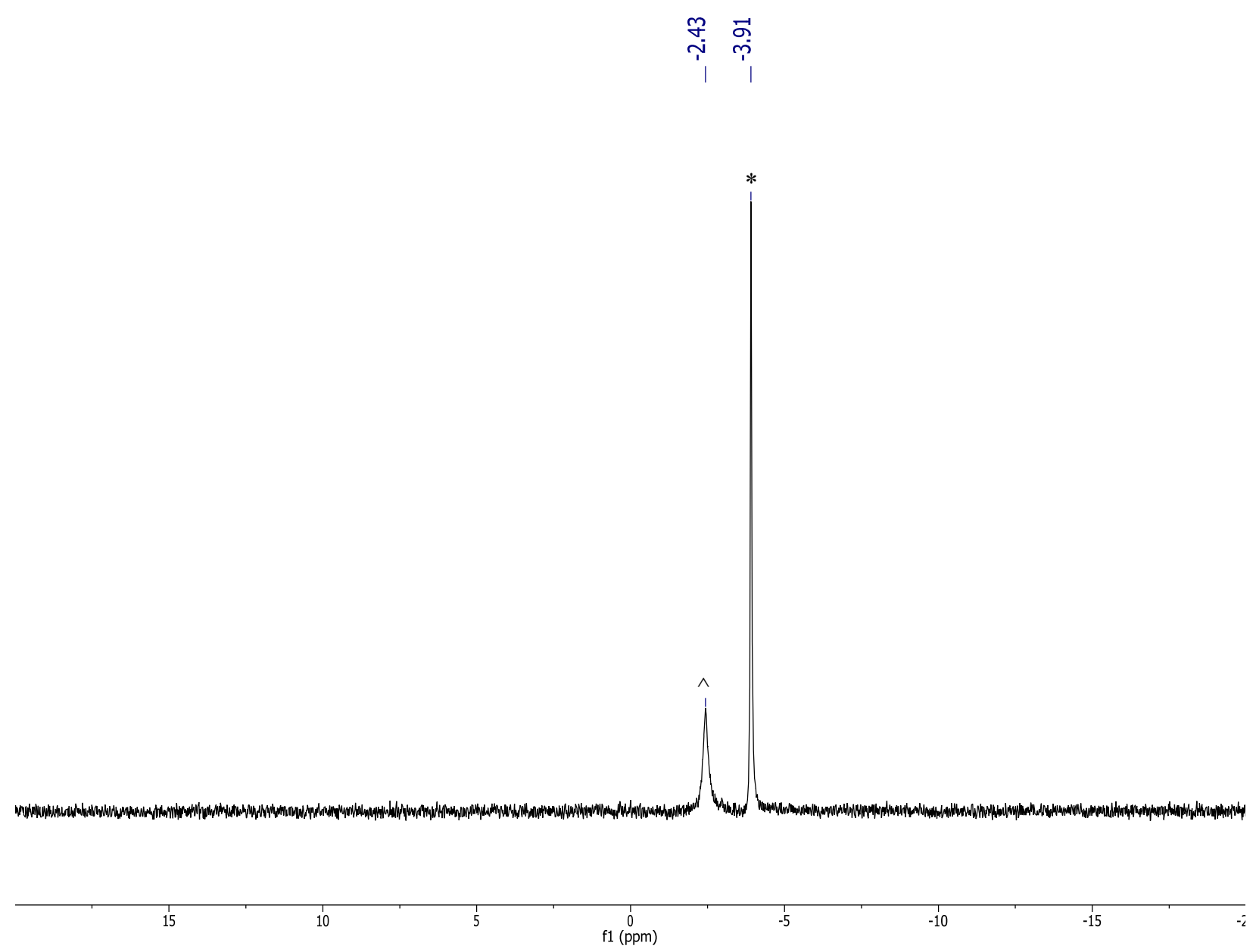

Figure S11: ${ }^{7} \operatorname{Li}\left\{{ }^{1} \mathrm{H}\right\}$ NMR spectrum $\left(\right.$ in $\mathrm{C}_{6} \mathrm{D}_{6}$ ) of an aliquot of the reaction to form $\mathbf{1}$ from 2 . * indicates the presence of $1, \wedge$ indicates the presence of 2 . Experimental Details: See Figure S10. 


$$
\text { ๗্) }
$$
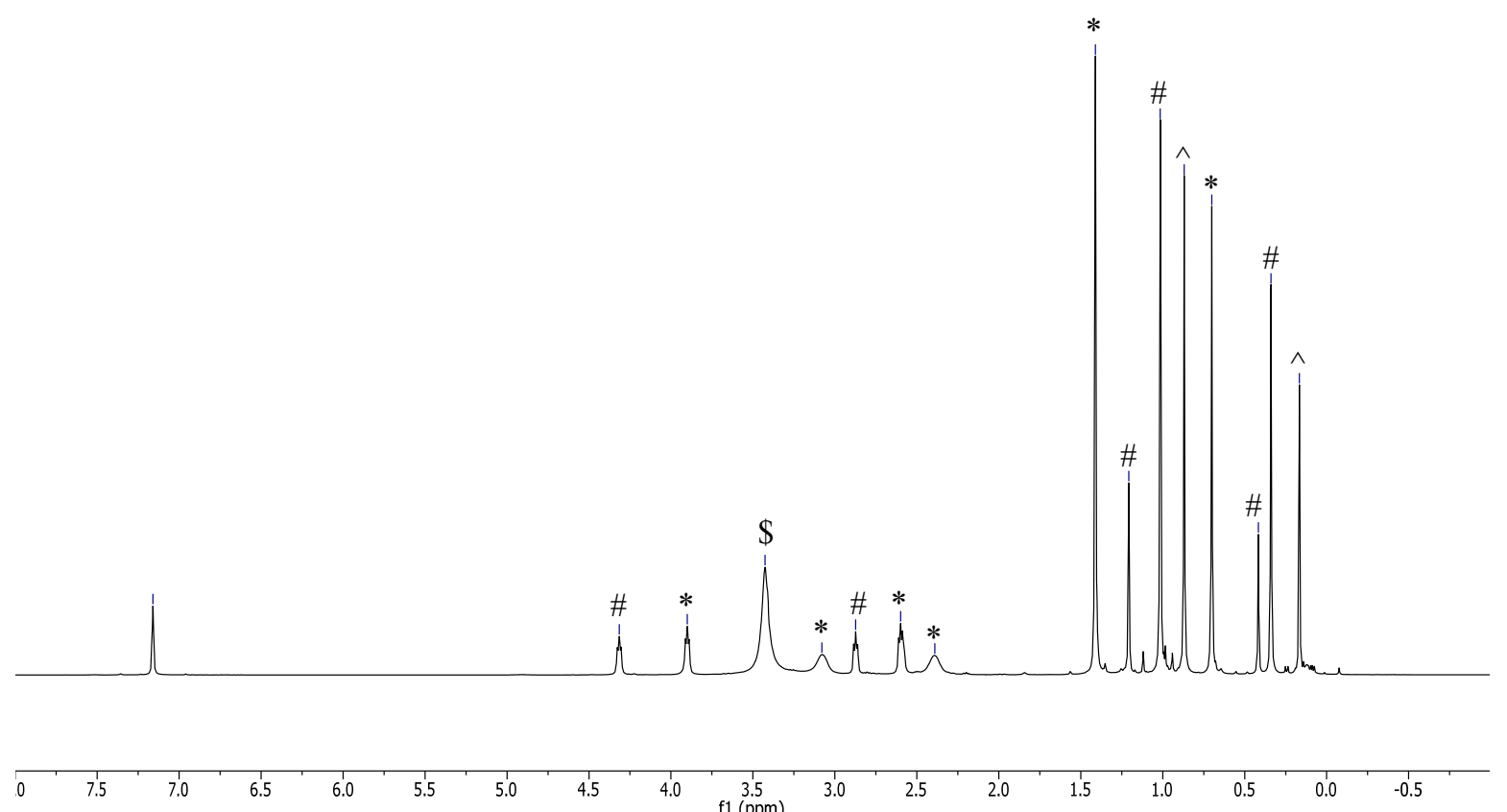

Figure S12: ${ }^{1} \mathrm{H}$ NMR spectrum of the reaction of 1 with ${ }^{\mathrm{t}} \mathrm{BuMe} \mathrm{SiCl}_{2} \mathrm{Sin} \mathrm{C}_{6} \mathrm{D}_{6}$. * indicates the presence of $\mathbf{1}, \#$ indicates the presence of $\mathbf{3}, \wedge$ indicates the presence of ${ }^{\mathrm{t}} \mathrm{BuMe} \mathrm{S}_{2} \mathrm{SiCl}$, and $\$$ indicates the presence of free 12-crown-4. Experimental Details: To a yellow $\mathrm{C}_{6} \mathrm{D}_{6}(0.5 \mathrm{~mL})$ solution of complex 1 (15 mg, $0.018 \mathrm{mmol})$, in an NMR tube, was added ${ }^{\mathrm{t}} \mathrm{BuMe} \mathrm{SiCl}_{2} \mathrm{Si} .0 \mathrm{mg}$, 0.020). This resulted in a gradual color change from yellow to red. After $24 \mathrm{~h}$, a ${ }^{1} \mathrm{H}$ NMR spectrum was recorded, which revealed the presence of complexes $\mathbf{1}$ and $\mathbf{3}$ in an approx. 1:1 ratio. 


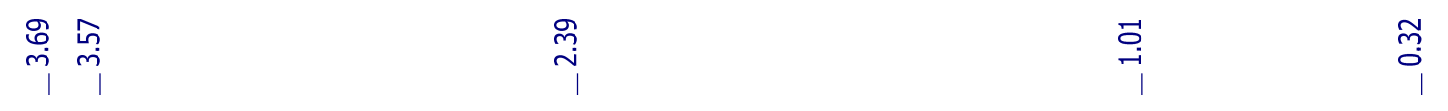

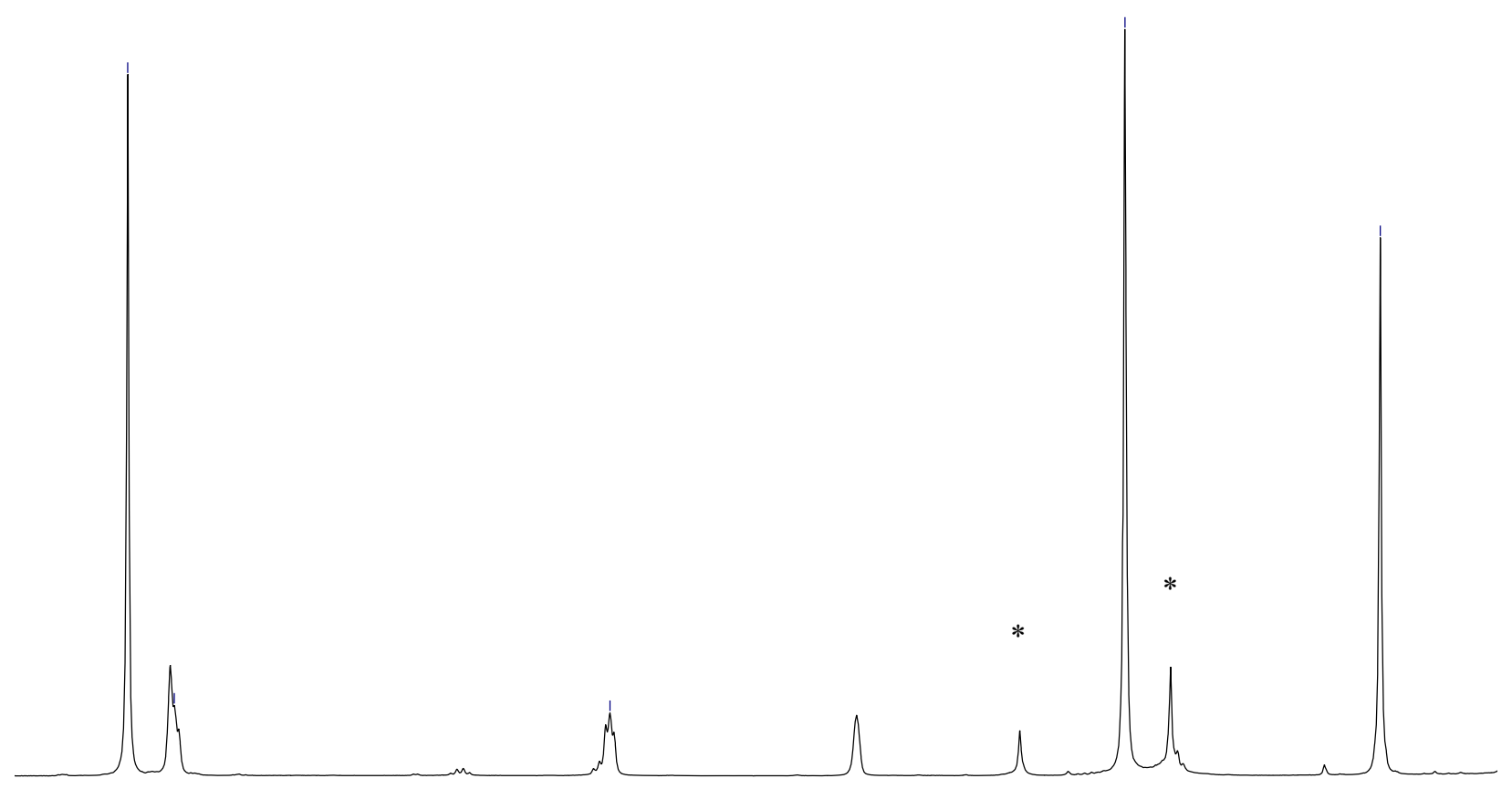

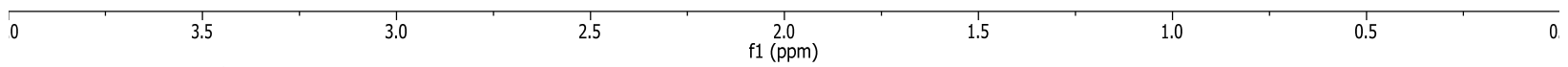

Figure S13: ${ }^{1} \mathrm{H}$ NMR spectrum of a mixture of 1 and $[\mathrm{Li}]\left[\mathrm{PF}_{6}\right]$ in THF- $d_{8} . *$ indicates the presence of hexanes. Experimental Details: Complex 1 (11.5 mg, $0.014 \mathrm{mmol})$ was dissolved in THF- $d_{8}(0.5 \mathrm{~mL})$ to give a yellow solution and the ${ }^{1} \mathrm{H}$ and ${ }^{7} \mathrm{Li}\left\{{ }^{1} \mathrm{H}\right\}$ NMR spectra were recorded. A colorless solution of $[\mathrm{Li}]\left[\mathrm{PF}_{6}\right](0.1 \mathrm{~mL}, 0.13 \mathrm{M}, 0.013 \mathrm{mmol})$ in THF- $d_{8}$ was then added to this solution. The ${ }^{1} \mathrm{H}$ and ${ }^{7} \mathrm{Li}\left\{{ }^{1} \mathrm{H}\right\}$ NMR spectra of the resulting solution were then recorded. ${ }^{1} \mathrm{H}$ NMR $\left(\mathrm{THF}-d_{8}, 25^{\circ} \mathrm{C}, 400 \mathrm{MHz}\right): \delta 3.69\left(\mathrm{~s}, \mathrm{OCH}_{2}\right), 3.57\left(\mathrm{CH}_{2}\right), 2.39\left(\mathrm{t}, J_{\mathrm{HH}}=4.5\right.$ $\left.\mathrm{Hz}, 6 \mathrm{H}, \mathrm{CH}_{2}\right), 1.01\left(\mathrm{~s}, 27 \mathrm{H}, \mathrm{C}\left(\mathrm{CH}_{3}\right)_{3}\right), 0.32\left(\mathrm{~s}, 18 \mathrm{H}, \mathrm{Si}\left(\mathrm{CH}_{3}\right)_{2}\right) .{ }^{7} \mathrm{Li}\left\{{ }^{1} \mathrm{H}\right\} \mathrm{NMR}\left(\mathrm{THF}-d_{8}, 25{ }^{\circ} \mathrm{C}\right.$, $155 \mathrm{MHz}): \delta-0.85(\mathrm{~s}, \mathrm{br}),-3.66(\mathrm{~s}, \mathrm{br})$. 


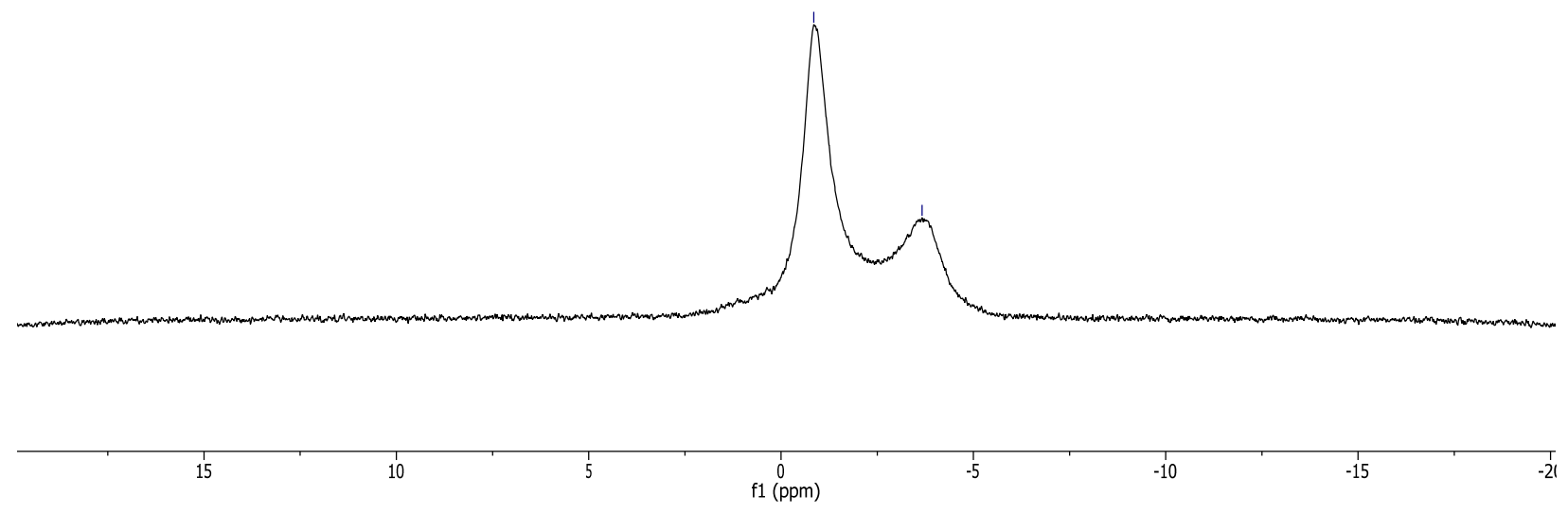

Figure S14: ${ }^{7} \mathrm{Li}$ NMR spectrum of a mixture of 1 and $[\mathrm{Li}]\left[\mathrm{PF}_{6}\right]$ in THF- $d_{8}$. Experimental Details: See Figure S13. 
Table S1. Crystallographic details for complexes 1 - 3.

\begin{tabular}{|c|c|c|c|}
\hline & $1 \cdot \mathrm{C}_{6} \mathrm{H}_{6}$ & $2 \cdot 0.5 \mathrm{C}_{7} \mathrm{H}_{8}$ & 3 \\
\hline Formula & $\mathrm{C}_{38} \mathrm{H}_{79} \mathrm{CeLiN}_{4} \mathrm{O}_{5} \mathrm{Si}_{3}$ & $\mathrm{C}_{71} \mathrm{H}_{154} \mathrm{Ce}_{2} \mathrm{Li}_{2} \mathrm{~N}_{10} \mathrm{O}_{14} \mathrm{Si}_{6}$ & $\mathrm{C}_{30} \mathrm{H}_{72} \mathrm{CeN}_{4} \mathrm{OSi}_{4}$ \\
\hline Crystal Habit, Color & Block, Yellow & Needles, Orange-red & Block, red \\
\hline Crystal Size (mm) & $0.20 \times 0.20 \times 0.10$ & $0.25 \times 0.10 \times 0.10$ & $\begin{array}{l}0.15 \times 0.15 \times \\
0.10\end{array}$ \\
\hline MW (g/mol) & 903.38 & 1834.70 & 757.40 \\
\hline crystal system & Triclinic & Monoclinic & Monoclinic \\
\hline space group & P-1 & $\mathrm{C} 2 / \mathrm{c}$ & $\mathrm{P} 2{ }_{1} / \mathrm{n}$ \\
\hline $\mathrm{a}(\AA)$ & $11.745(3)$ & $37.34(1)$ & $11.8041(8)$ \\
\hline $\mathrm{b}(\AA)$ & $12.572(3)$ & $11.365(3)$ & $20.306(1)$ \\
\hline $\mathrm{c}(\AA)$ & $18.886(4)$ & $22.312(7)$ & $17.372(1)$ \\
\hline$\alpha\left({ }^{\circ}\right)$ & $85.344(4)$ & 90.00 & 90.00 \\
\hline$\beta\left(^{\circ}\right)$ & $78.547(4)$ & $99.875(8)$ & $93.916(4)$ \\
\hline$\gamma\left(\left(^{\circ}\right)\right.$ & $63.000(4)$ & 90.00 & 90.00 \\
\hline $\mathrm{V}\left(\AA^{3}\right)$ & $2435.2(9)$ & $9328(5)$ & $4154.1(5)$ \\
\hline Z & 2 & 4 & 4 \\
\hline $\mathrm{T}(\mathrm{K})$ & $100(2)$ & $100(2)$ & $100(2)$ \\
\hline$\lambda(\AA)$ & 0.71073 & 0.71073 & 0.71073 \\
\hline GOF & 0.784 & 0.959 & 1.019 \\
\hline $\begin{array}{l}\text { Density (calcd) } \\
\left(\mathrm{Mg} / \mathrm{m}^{3}\right)\end{array}$ & 1.232 & 1.306 & 1.211 \\
\hline $\begin{array}{l}\text { Absorption } \\
\text { coefficient }\left(\mathrm{mm}^{-1}\right)\end{array}$ & 1.048 & 1.099 & 1.236 \\
\hline $\mathrm{F}_{000}$ & 956 & 3872 & 1608 \\
\hline Total no Reflections & 10700 & 43066 & 30724 \\
\hline Unique Reflections & 8850 & 9518 & 9396 \\
\hline Final $\mathrm{R}$ indices* & $\begin{array}{l}\mathrm{R}_{1}=0.0517 \\
\mathrm{wR}_{2}=0.1105\end{array}$ & $\begin{array}{l}\mathrm{R}_{1}=0.0671 \\
\mathrm{wR}_{2}=0.1545\end{array}$ & $\begin{array}{l}\mathrm{R}_{1}=0.0501 \\
\mathrm{wR}_{2}=0.1071\end{array}$ \\
\hline $\begin{array}{l}\text { Largest Diff. peak } \\
\text { and hole }\left(\mathrm{e}^{-} \mathrm{A}^{-3}\right)\end{array}$ & $1.618,-0.923$ & $1.834,-1.215$ & $1.505,-1.387$ \\
\hline
\end{tabular}

* For $[\mathrm{I}>2 \sigma(\mathrm{I})]$ 


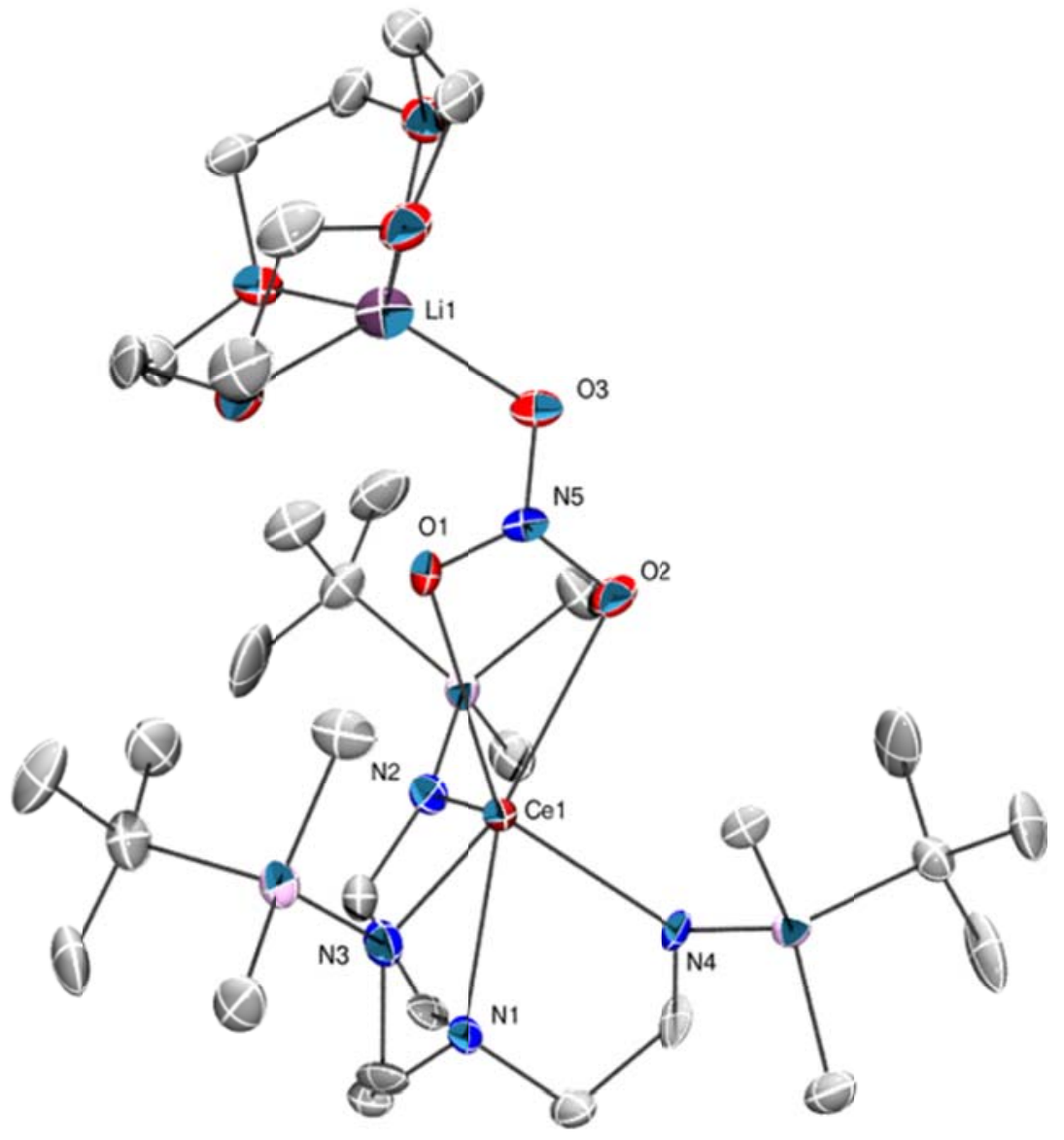

Figure S15: ORTEP diagram of $\mathbf{2}$ shown with 50\% probability ellipsoids. Hydrogen atoms and one molecule of toluene are omitted for clarity. Selected bond distances $(\AA)$ and angles $\left(^{\circ}\right)$ : Ce1-N4 = 2.360(6), Ce1-N2 = 2.361(7), Ce1-N3 =2.401(7), Ce1-N1 = 2.674(7), Ce1-O2 = 2.724(6), Ce1-O1 = 2.745(6), O3-Li1 = 2.01(2), N1-Ce1-O1 = 149.9(2), N1-Ce1-O2 = 159.6(2), $\mathrm{O} 2-\mathrm{Ce} 1-\mathrm{O} 1=46.4(2), \mathrm{N} 5-\mathrm{O} 3-\mathrm{Li1}=115.6(7)$. 


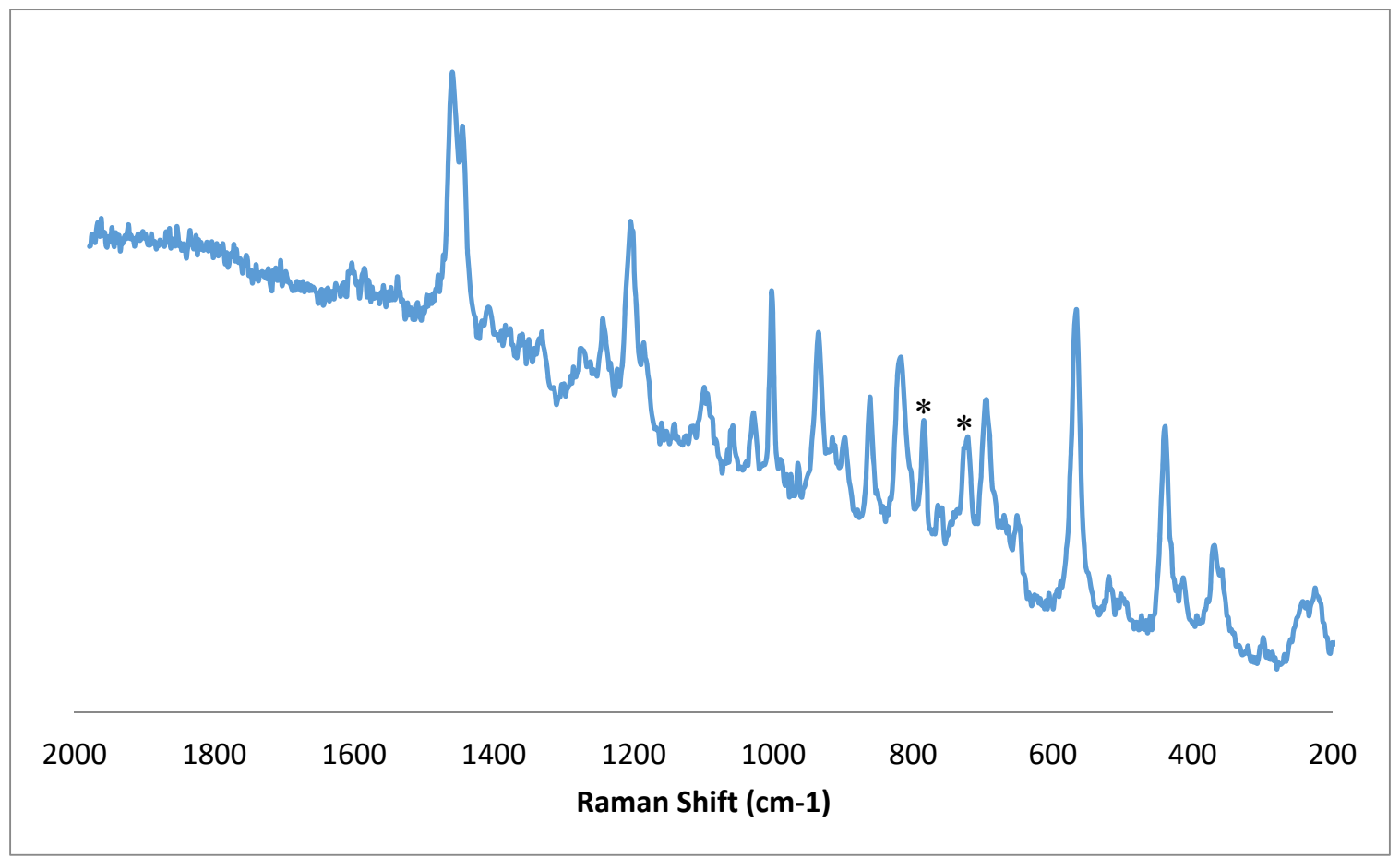

Figure S16: Raman spectrum of 1. * indicates resonances assigned the $v(\mathrm{Ce}-\mathrm{O})$ stretches. 


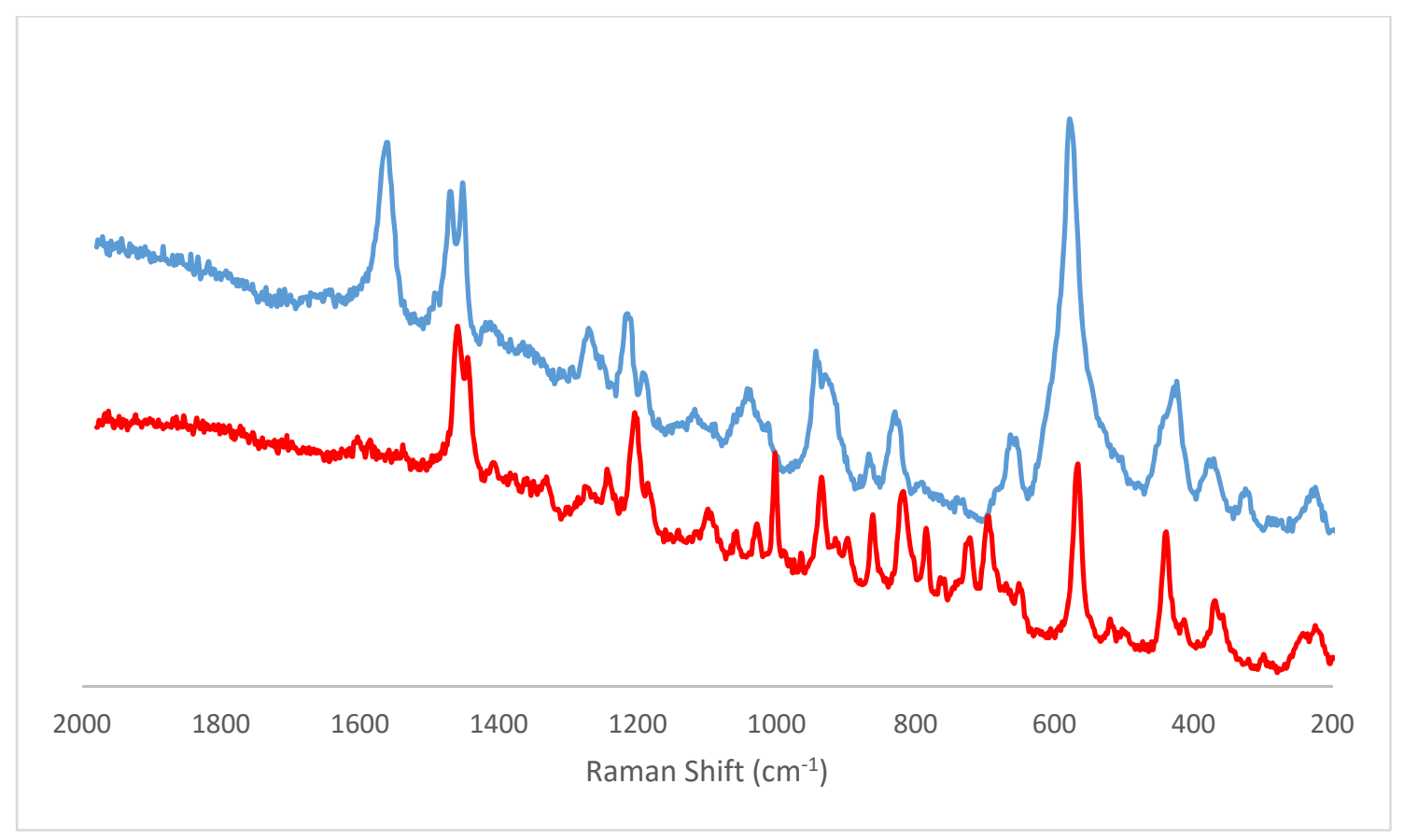

Figure S17: Overlay of the Raman spectra of complexes 1 (red line) and 2 (blue line). 


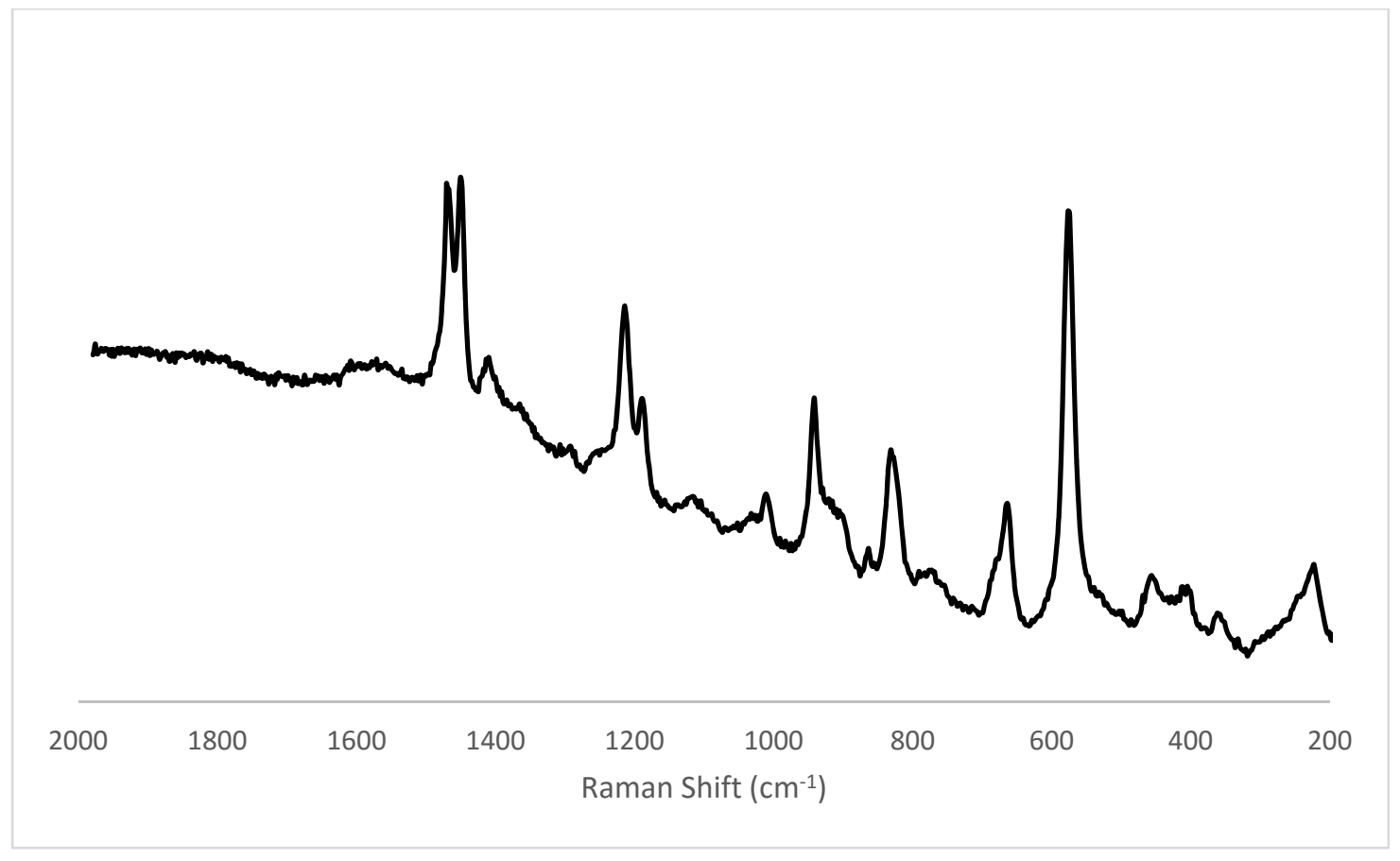

Figure S18: Raman spectrum of 3 .

S27 


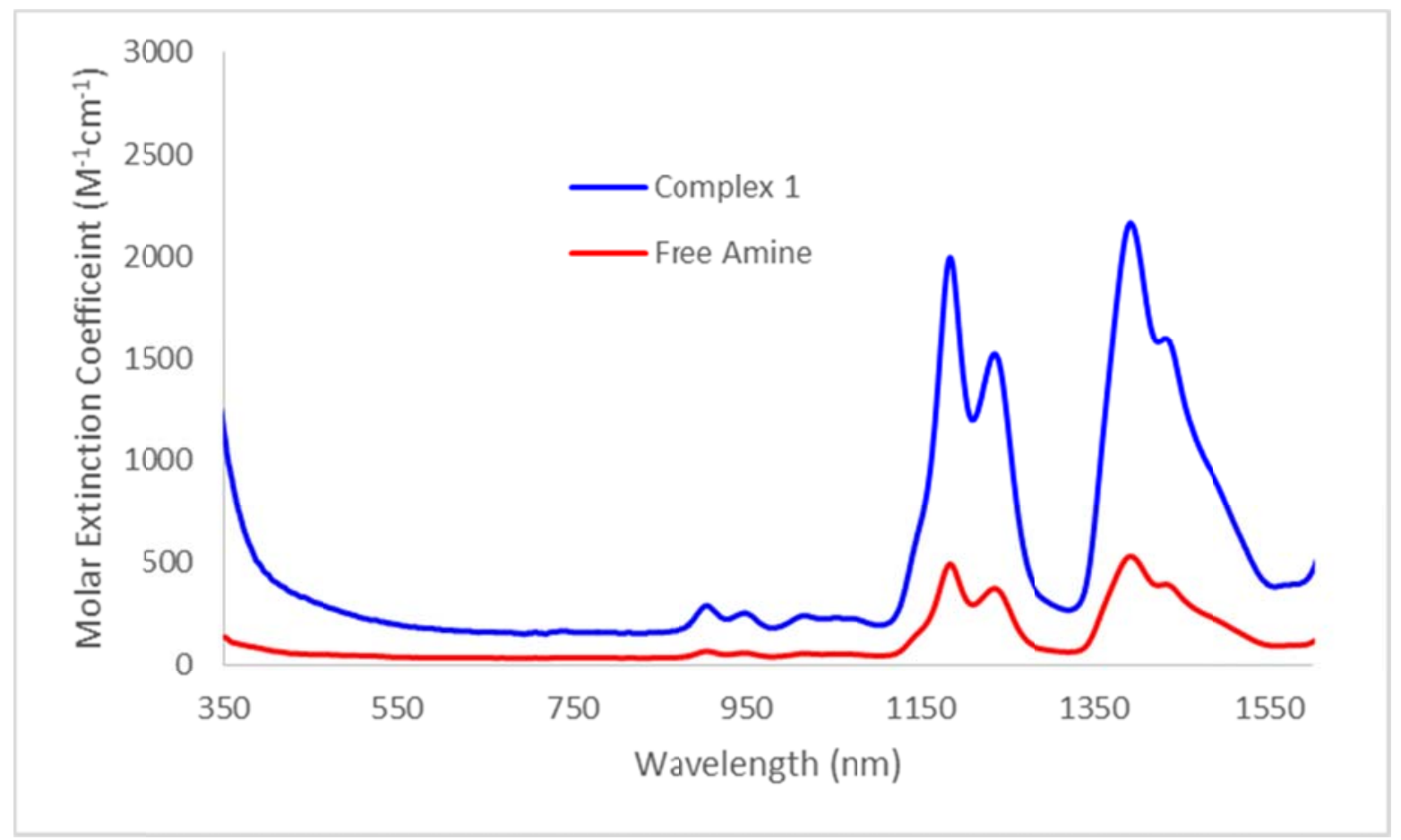

Figure S19: Overlay of the UV/Vis/NIR spectra of $0.10 \mathrm{mM} \mathrm{Et}_{2} \mathrm{O}$ solutions of 1 and $\mathrm{H}_{3} \mathrm{NN}_{3}$. 


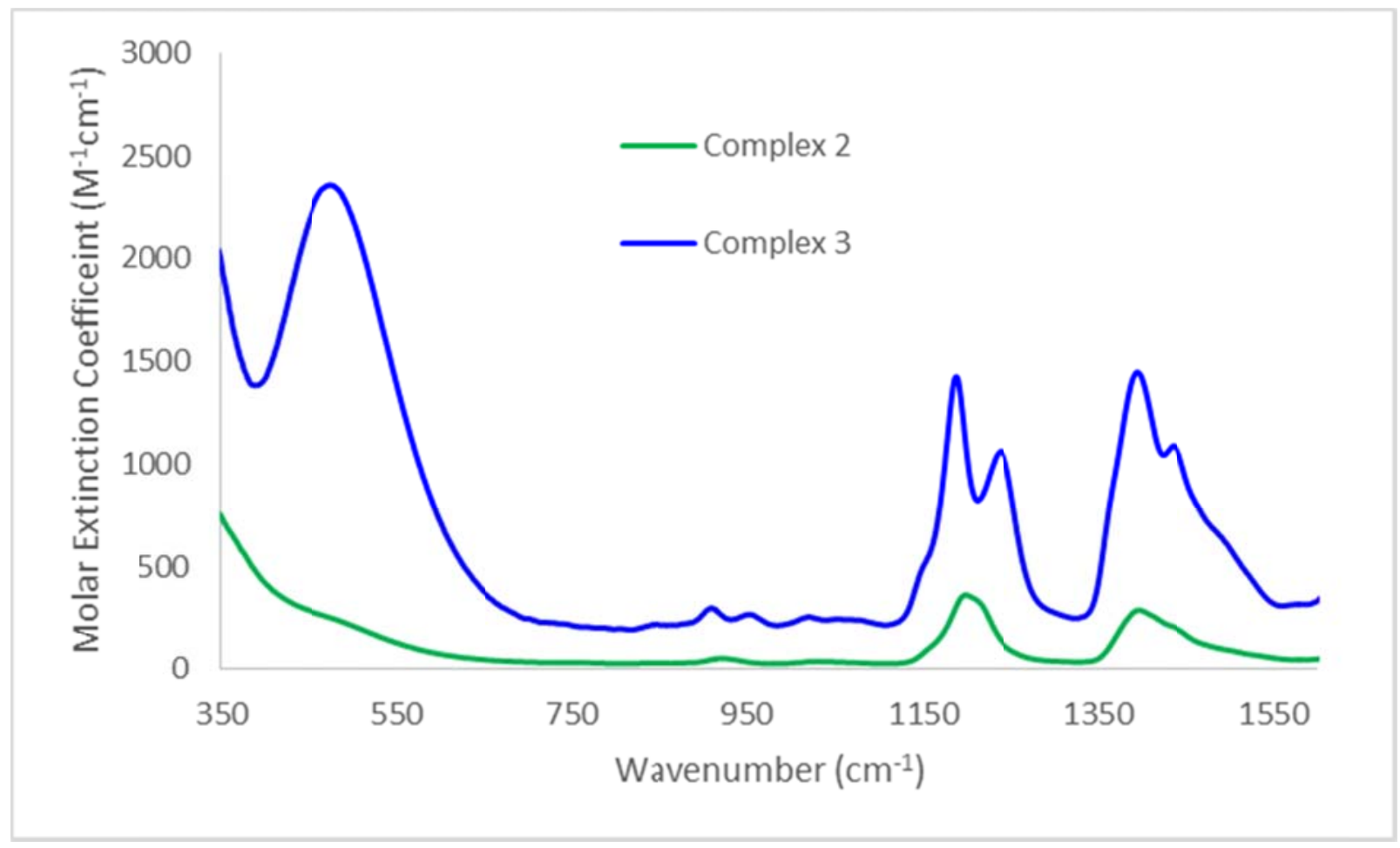

Figure S20: Overlay of the UV/Vis/NIR spectra of $0.10 \mathrm{mM} \mathrm{Et}_{2} \mathrm{O}$ solutions of complexes 2 and 3. 


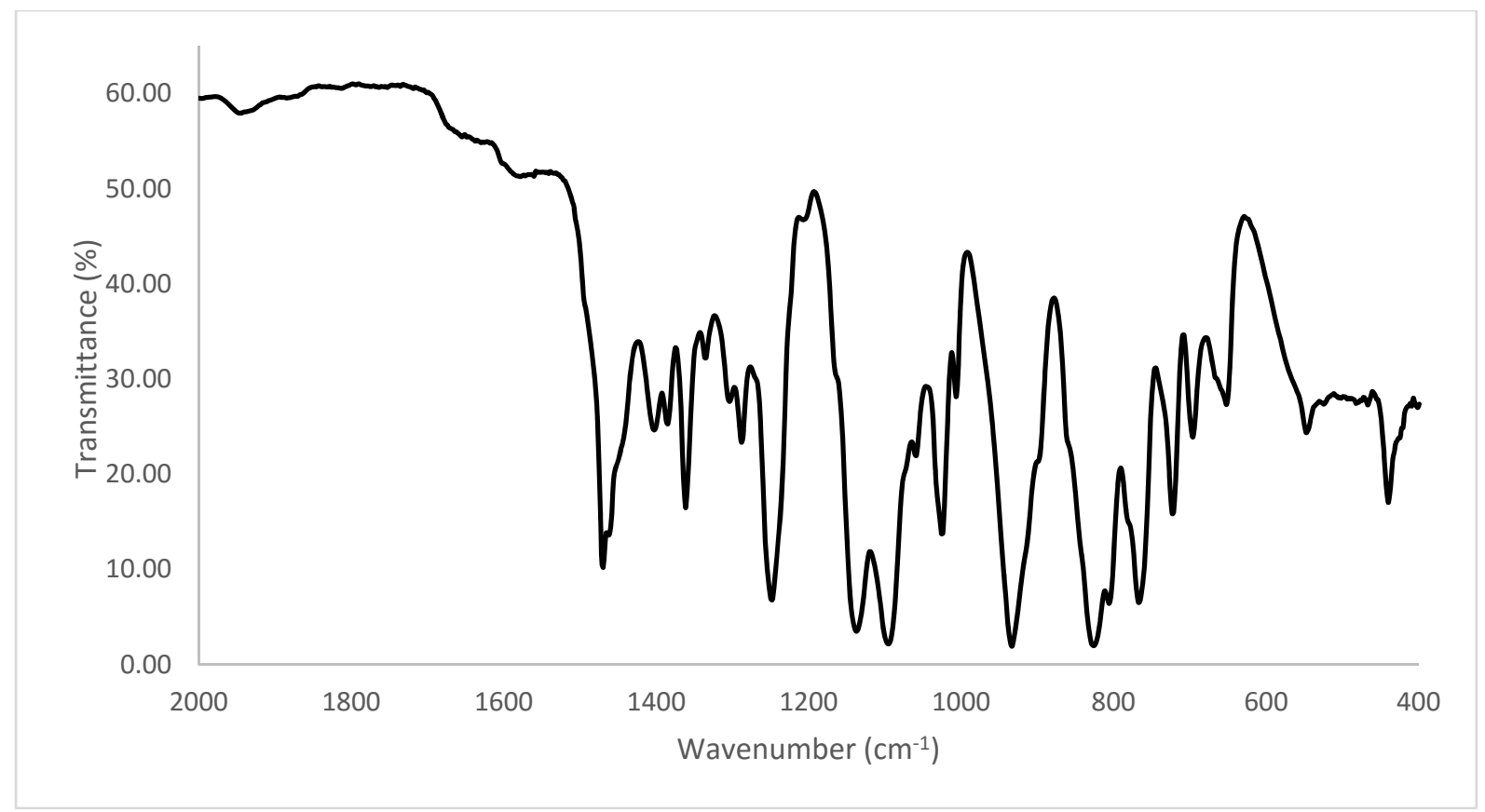

Figure S21: Partial IR spectrum of [Li(12-crown-4)][( $\left.\left.\mathrm{NN}^{\prime}{ }_{3}\right) \mathrm{Ce}(\mathrm{O})\right](\mathbf{1})$ as a $\mathrm{KBr}$ pellet. 


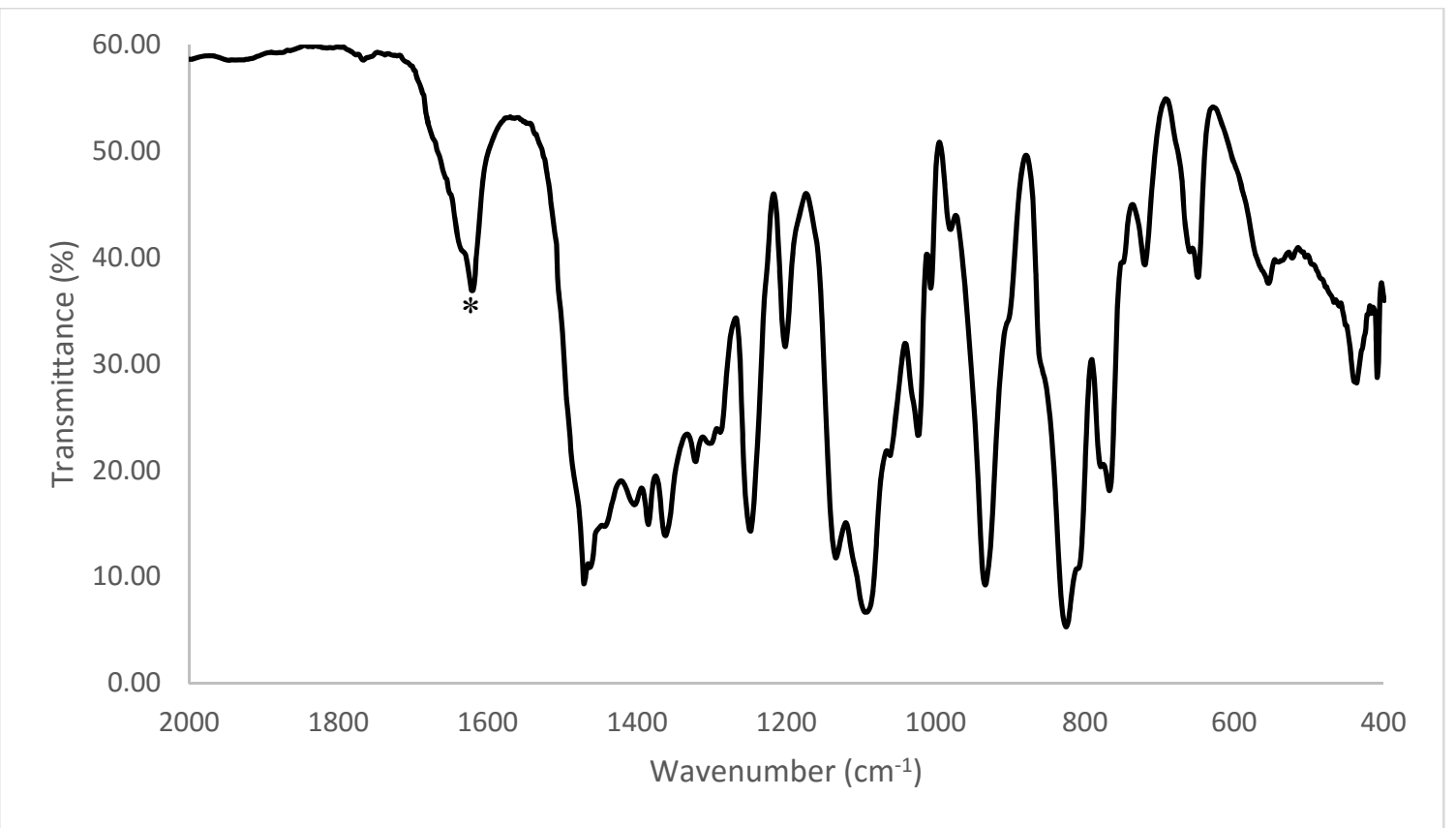

Figure S22: Partial IR spectrum of [Li(12-crown-4)][( $\left.\left.\mathrm{NN}_{3}{ }_{3}\right) \mathrm{Ce}\left(\mathrm{K}^{2}-\mathrm{O}_{2} \mathrm{NO}\right)\right](2)$ as a $\mathrm{KBr}$ pellet. * indicates vibration assigned the $\mathrm{v}(\mathrm{N}-\mathrm{O})$ stretch. 


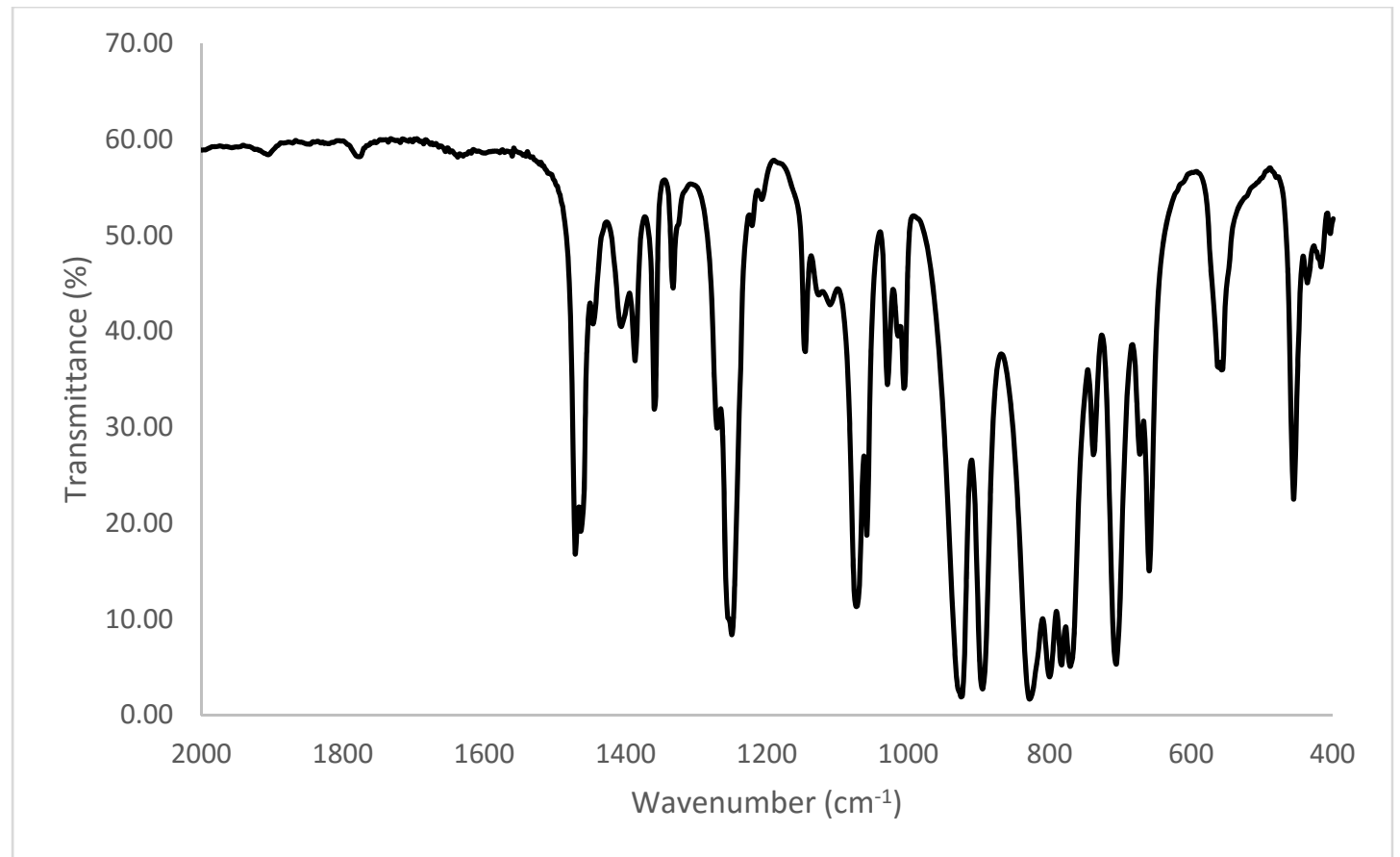

Figure S23: Partial IR spectrum of $\left[\left(\mathrm{NN}_{3}{ }_{3}\right) \mathrm{Ce}\left(\mathrm{OSi}^{\mathrm{t}} \mathrm{BuMe}_{2}\right)\right](3)$ as a $\mathrm{KBr}$ pellet. 


\section{Computational details}

Density functional theory calculations were carried out using the PBE functional, ${ }^{9,10}$ as implemented in the Gaussian 09 Rev. D.01 quantum chemistry code, ${ }^{11}$ in conjunction with the D3 dispersion corrections due to Grimme et al. ${ }^{12}$ A (14s 13p 10d 8f)/[10s 9p 5d 4f] segmented valence basis set with Stuttgart-Bonn variety relativistic pseudopotential was used for Ce, ${ }^{13}$ and 6-31 $\mathrm{G}^{*}$ basis sets were used for all other atoms. The ultrafine integration grid was employed, as were the SCF and geometry convergence criteria. Geometries were verified as true minima via harmonic vibrational frequency analysis. Quantum Theory of Atoms-In-Molecules analyses were performed using the AIMAll programme version 15.05.18, ${ }^{14}$ using .wfx files from Gaussian G09 as input. Natural Bond Orbital analyses were performed with the NBO6 code, ${ }^{15}$ interfaced with Gaussian 09. 
Converged Cartesian coordinates ( $\AA$ ) and SCF energies (H)

Compound 1

SCF energy $=-3206.9684032$

C $-4.210682-3.203273 \quad 0.742957$

C $-2.433519-4.7919401 .560409$

C $-2.691981-3.4358640 .874003$

C $-2.149909-5.109458-1.713209$

C $-2.091161-2.3189691 .748473$

C $-2.725630-2.101998-1.940018$

C $0.865476-4.040527-1.039816$

C $-5.0749661 .033005-1.359039$

C -4.9759720 .9149691 .043386$

C $2.107591-3.835650-0.165105$

C $-4.104022 \quad 1.330726-2.504728$

C $-3.917378 \quad 1.1697672 .119692$

C $5.108137 \quad 1.212719-2.533613$

C $2.983174 \quad 0.1235695 .225124$

C $2.3407901 .190156-4.695214$

C $2.549720-1.516895-2.620500$

C $3.403032-2.261392-1.570806$

C $-0.1838340 .112110 \quad 4.027754$

C $3.455198-2.0988720 .911602$

C $2.545932-1.7017242 .084953$

C $4.0931813 .496712-2.741198$

C $3.9020502 .089107-2.141690$

C 2.4072932 .5024534 .752796

C 2.7578601 .1492454 .093203

C $-3.5542213 .633962-1.980934$

C $-3.4936503 .511791 \quad 1.652854$

C $3.8314092 .193363-0.605086$

C $4.0544391 .327524 \quad 3.277113$ 

C $\quad 0.818400 \quad 2.434043-2.326804$
C -2.371596 4.405193-1.399833
C $-2.365808 \quad 4.354882 \quad 1.061705$
$\begin{array}{llll}\text { C } & 0.733118 & 2.216052 & 2.004058\end{array}$
N - $0.146628-3.025832-0.759826$
N $2.678755-2.477327-0.292166$
N $1.963304-0.288784-2.084969$
N $1.680629-0.5776481 .730322$
O $-4.2807350 .819426-0.196719$
O $-1.0500710 .351668-0.251866$
O $-3.1047292 .285986-2.125624$
$\begin{array}{llll}\text { O } & -2.983482 & 2.180985 & 1.723605\end{array}$
O $-1.900383 \quad 3.812110-0.182454$
Ce $0.529748-0.804528-0.324575$
Si - $1.840744-3.419942-0.881771$
Si $2.260371 \quad 1.271747-2.788627$
Si $1.284376 \quad 0.6379102 .918978$
Li -2.244100 $1.686441-0.237907$
H -3.7639003 .8862882 .662758$
H -4.3982503 .5660421 .012164$
H -2.6898905 .4064570 .941681$
H -1.4974714 .3208581 .740863$
H -1.522310 $4.344811-2.101335$
H -2.639444 5.468541 -1.247702
H $-4.4327503 .697890-1.305929$
H -3.844566 4.059417-2.964603
H -4.4042801 .4289353 .081263$
H -3.3010540 .2695562 .264611$
H -5.526140 -0.019493 1.274860
H $-5.716930 \quad 1.7417580 .995700$
H $-5.7754751 .878493-1.185413$
H $-5.6818590 .139283-1.609988$ 
H $-3.5364600 .422062-2.757444$

H $-4.661942 \quad 1.670081-3.400457$

H $-2.172560-1.327766 \quad 1.263895$

H -2.603136 -2.265733 2.733086

H -1.018917 -2.495646 1.951389

H -2.902287 -5.630243 1.014260

H -1.350413 -5.003164 1.636493

H -2.843401 -4.797290 2.591626

H -4.427275 -2.202487 0.324844

H $-4.694369-3.9520220 .087681$

H $-4.706391-3.2681741 .734545$

H -3.804338 -2.311994-2.057416

H -2.597193 -1.114789-1.462769

H -2.264421 -2.062881 -2.943501

H - $1.769848-5.104928-2.750110$

H $-1.662693-5.944289-1.180708$

H $-3.232310-5.328884-1.754784$

H -1.0862700 .0127413 .398291$

H $-0.003153-0.8683634 .502674$

H -0.4042780 .8432664 .827272$

H $\quad 0.002819 \quad 1.962285 \quad 1.216828$

H 0.2466462 .9134262 .710251

H 1.5840252 .7378301 .532757

H $1.459647 \quad 2.4547915 .321280$

H $3.2024832 .799351 \quad 5.467659$

H 2.3143963 .3134244 .009363

H 3.9276342 .0682772 .467042

H $4.880537 \quad 1.683473 \quad 3.927160$

H 4.3855610 .3857892 .806085

H $3.272964-0.8729464 .848677$

H 3.7942740 .4653705 .901299

H $2.075467-0.0082505 .841338$ 
H $2.504604 \quad 2.188526-5.138547$

H $3.1528760 .532143-5.051747$

H $1.391750 \quad 0.792403-5.096174$

H $0.978173 \quad 3.433346-2.772668$

H $-0.136302 \quad 2.030273-2.707077$

H $\quad 0.7052572 .564154-1.236500$

H $6.054645 \quad 1.657536-2.162917$

H $5.0315590 .199898-2.099884$

H $5.203046 \quad 1.103869-3.629796$

H $5.0286103 .959518-2.364053$

H $4.1644563 .470428-3.844076$

H $3.2631334 .175475-2.472869$

H $3.0418992 .897873-0.284382$

H $3.608707 \quad 1.217710-0.135173$

H $4.7906382 .562425-0.186577$

H $4.056147-1.211406 \quad 0.651037$

H $4.153877-2.9150751 .211068$

H $1.963643-2.5923842 .420024$

H $3.232419-1.4836392 .929846$

H $3.765636-3.229126-1.981880$

H $4.290403-1.644010-1.351289$

H $3.204244-1.347447-3.504217$

H $1.757469-2.209377-2.982791$

H $\quad 1.799781-3.9675280 .886518$

H $2.883207-4.604879-0.391103$

H $1.180998-4.038117-2.109949$

H $\quad 0.517439-5.079422-0.847407$ 
[K(18-crown-6)] [Ce(O)(NR2) $\left.)_{3}\right]$

SCF energy $=-4689.8041642$

Ce $-1.4108420 .000235-0.001398$

$\begin{array}{lllll}\mathrm{O} & 0.492591 & 0.005523 & 0.007995\end{array}$

$\mathrm{N}-1.919742 \quad 2.290701-0.322442$

$\mathrm{N}-1.910081-1.424003-1.826535$

Si $-0.8365493 .190512-1.348725$

Si -3.201946 - $1.066428-2.948915$

Si -3.220111 $3.078075 \quad 0.541260$

Si $-0.832233-2.769507-2.079522$

K 3.1013690 .0008180 .003580

N $-1.924807-0.869852 \quad 2.140013$

Si -3.222022 $-2.015943 \quad 2.385577$

Si $-0.847361-0.4248363 .435330$

O $4.133251-2.818478-0.050122$

$\begin{array}{lllll}\text { O } & 3.786955 & 2.783089 & 0.064335\end{array}$

O $4.1301131 .460106-2.413878$

O $3.786326-1.4412342 .384352$

O $3.787952-1.337419-2.437129$

$\begin{array}{lllll}\text { O } & 4.123533 & 1.367483 & 2.477508\end{array}$

C $-1.651248-4.319647-2.833260$

H $-2.512440-4.654356-2.229325$

H $-0.922087-5.150100-2.872428$

H - $2.009149-4.143067-3.862599$

C $-0.115682-3.334695-0.400544$

H $0.512976-4.236095-0.524502$

H $-0.926364-3.5929520 .303384$

H $\quad 0.491321-2.5413910 .071867$

C $0.615020-2.308780-3.236192$

H $0.225161-1.903015-4.186335$

H $1.247927-3.184234-3.477209$

H $1.254518-1.537820-2.774884$

C $-2.563264-0.797435-4.728637$

H - $1.784704-0.014788-4.761799$

H $-3.382697-0.492968-5.404825$

H - $2.120968-1.724140-5.137307$

C $-4.1005760 .522816-2.408713$

H $-4.6153270 .387321-1.438551$

H $-4.8784850 .776592-3.151906$

H -3.429512 $1.391395-2.302028$

C $-4.565714-2.396742-3.042399$

H $-4.215742-3.339875-3.493033$

H -5.406833 -2.022673 -3.654957 
$\begin{array}{llll}\text { H } & -4.957388 & -2.627565 & -2.036811 \\ \text { C } & -2.594460 & 4.486701 & 1.669062 \\ \text { H } & -1.824913 & 4.124630 & 2.373627 \\ \text { H } & -3.421187 & 4.921061 & 2.260096 \\ \text { H } & -2.144169 & 5.303123 & 1.075620 \\ \text { C } & -4.119172 & 1.812047 & 1.642856 \\ \text { H } & -4.631663 & 1.039295 & 1.038968 \\ \text { H } & -4.898743 & 2.326286 & 2.234191 \\ \text { H } & -3.447978 & 1.285793 & 2.342129 \\ \text { C } & -4.581007 & 3.818005 & -0.571935 \\ \text { H } & -4.231617 & 4.680719 & -1.162555 \\ \text { H } & -5.426485 & 4.158739 & 0.053962 \\ \text { H } & -4.966444 & 3.060245 & -1.275783 \\ \text { C } & -0.119530 & 2.031515 & -2.688530 \\ \text { H } & 0.483712 & 1.218448 & -2.245952 \\ \text { H } & 0.512989 & 2.595406 & -3.399241 \\ \text { H } & -0.930997 & 1.561296 & -3.271738 \\ \text { C } & 0.609137 & 3.948487 & -0.358801 \\ \text { H } & 0.217664 & 4.558735 & 0.474123 \\ \text { H } & 1.245006 & 4.601573 & -0.986697 \\ \text { H } & 1.245653 & 3.156882 & 0.070165 \\ \text { C } & -1.649321 & 4.629975 & -2.302341 \\ \text { H } & -2.505752 & 4.281152 & -2.904972 \\ \text { H } & -0.915106 & 5.088029 & -2.990877 \\ \text { H } & -2.012853 & 5.424756 & -1.627653 \\ \text { C } & -2.592983 & -3.694599 & 3.044985 \\ \text { H } & -1.818414 & -4.121331 & 2.383385 \\ \text { H } & -3.417351 & -4.426706 & 3.121644 \\ \text { H } & -2.148553 & -3.586678 & 4.051045 \\ \text { C } & -4.589446 & -1.426440 & 3.577736 \\ \text { H } & -4.243213 & -1.342439 & 4.620827 \\ \text { H } & -5.431558 & -2.142687 & 3.559051 \\ \text { H } & -4.978421 & -0.440411 & 3.270273 \\ \text { C } & -4.113477 & -2.340370 & 0.734688 \\ \text { H } & -4.623823 & -1.431268 & 0.363784 \\ \text { H } & -4.894241 & -3.108858 & 0.882455 \\ \text { H } & -3.438736 & -2.684339 & -0.067004 \\ \text { C } & -0.136743 & 1.317587 & 3.102220 \\ \text { H } & 0.463418 & 1.343286 & 2.174808 \\ \text { H } & 0.497762 & 1.651464 & 3.944387 \\ \text { H } & -0.950198 & 2.055977 & 2.990137 \\ \text { C }-1.665757 & -0.322287 & 5.156244 \\ \text { H } & -2.524753 & 0.370923 & 5.152737 \\ \text { H } & -0.935510 & 0.047462 & 5.899758\end{array}$ 

H $-2.026743-1.3054555 .505713$
C $0.603317-1.6547243 .600905$
H $0.216228-2.6827543 .713887$
H $1.236646-1.4335594 .481170$
H $1.241218-1.6292272 .701771$
C 4.1907993 .4272141 .268270
H 3.8344974 .4794971 .283353
H 5.2988173 .4312221 .352140
C $4.251084-0.7688573 .550529$
H $5.360324-0.702543 \quad 3.542165$
H $3.940983-1.3188994 .464668$
C $4.2571123 .456954-1.098849$
H $5.3664773 .415233-1.147755$
H $3.9481954 .523968-1.080211$
C 3.5840412 .6882762 .444292
H 3.8314643 .2362003 .379729
H 2.4789722 .6589932 .346001
C $3.656312-3.413802-1.256354$
H $2.551425-3.358038-1.309815$
H $3.952610-4.484454-1.306951$
C $3.5937290 .773056-3.543762$
H $3.846090 \quad 1.309296-4.484541$
H $2.4881380 .704948-3.474146$
C $3.6507532 .801277-2.323231$
H $2.5461202 .817236-2.244114$
H $3.9427783 .382138-3.225517$
C $3.599896-3.4555341 .110267$
H $3.856788-4.5373341 .116142$
H $2.494019-3.365413 \quad 1.134720$
C 3.6414830 .6180963 .592283
H 2.5369870 .5395543 .563058
H $3.929348 \quad 1.1098624 .547268$
C $4.201392-2.8024842 .338695$
H $3.849691-3.3455353 .241973$
H $5.309970-2.8678912 .300095$
C $4.260621-2.680849-2.437259$
H $5.370036-2.699927-2.376462$
H $3.953041-3.199979-3.370115$
C $4.197728-0.616196-3.594546$
H $3.844420-1.127708-4.515356$
H $5.306055-0.547573-3.635157$ 


\section{References:}

(1) Roussel, P.; Alcock, N. W.; Scott, P. Inorg. Chem. 1998, 37, 3435-3436.

(2) Niemeyer, M. Z. Anorg. Allg. Chem. 2006, 632, 1449-1456.

(3) Harris, R. K.; Becker, E. D.; Cabral De Menezes, S. M.; Granger, P.; Hoffman, R. E.; Zilm, K. W. Pure Appl. Chem. 2008, 80, 59-84.

(4) Harris, R. K.; Becker, E. D.; Cabral De Menezes, S. M.; Goodfellow, R.; Granger, P. Pure Appl. Chem. 2001, 73, 1795-1818.

(5) SMART Apex II, Version 2.1, Bruker AXS Inc., Madison, WI, 2005,

(6) SAINT Software User's Guide, Version 7.34a, Bruker AXS Inc., Madison, WI, 2005,

(7) SADABS, Sheldrick, G. M., University of Gottingen, Germany, 2005,

(8) SHELXTL PC, Version 6.12, Bruker AXS Inc., Madison, WI, 2005,

(9) Perdew, J. P. B., K.; Ernzerhof, M. Phys. Rev. Lett. 1997, 78, 1396.

(10) Perdew, J. P. B., K.; Ernzerhof, M. Phys. Rev. Lett. 1996, 77, 3865.

(11) Gaussian 09, Revision D.01, Gaussian 09 Revision D.01; Frisch, M. J. T., G. W.; Schlegel, H. B.; Scuseria, G. E.; Robb, M. A.; Cheeseman, J. R.; Scalmani, G.; Barone, V.; Mennucci, B.; Petersson, G. A.; Nakatsuji, H.; Caricato, M.; Li, X.; Hratchian, H. P.; Izmaylov, A. F.; Bloino, J.; Zheng, G.; Sonnenberg, J. L.; Hada, M.; Ehara, M.; Toyota, K.; Fukuda, R.; Hasegawa, J.; Ishida, M.; Nakajima, T.; Honda, Y.; Kitao, O.; Nakai, H.; Vreven, T.; Montgomery, J. A.; Peralta, J. E.; Ogliaro, F.; Bearpark, M.; Heyd, J. J.; Brothers, E.; Kudin, K. N.; Staroverov, V. N.; Kobayashi, R.; Normand, J.; Raghavachari, K.; Rendell, A.; Burant, J. C.; Iyengar, S. S.; Tomasi, J.; Cossi, M.; Rega, N.; Millam, J. M.; Klene, M.; Knox, J. E.; Cross, J. B.; Bakken, V.; Adamo, C.; Jaramillo, J.; Gomperts, R.; Stratmann, R. E.; Yazyev, O.; Austin, A. J.; Cammi, R.; Pomelli, C.; Ochterski, J. W.; Martin, R. L.; Morokuma, K.; Zakrzewski, V. G.; Voth, G. A.; Salvador, P.; Dannenberg, J. J.; Dapprich, S.; Daniels, A. D.; Farkas, O.; Foresman, J. B.; Ortiz, J. V.; Cioslowski, J.; Fox, D. J., Gaussian, Inc., Wallington CT, 2009,

(12) Grimme, S.; Antony, J.; Ehrlich, S.; Krieg, H. J. Chem. Phys. 2010, 132, 154104.

(13) Cao, X.; Dolg, M. J. Mol. Struct. (TheoChem) 2002, 581, 139-147.

(14) AIMA11 v 15.05.18, Keith, T. A., AIMA11 v 15.05.18, http://aim.tkgristmill.com/, 2015, http://aim.tkgristmill.com/

(15) Glendening, E. D.; Badenhoop, J. K.; Reed, A. E.; Carpenter, J. E.; Bohmann, J. A.; Morales, C. M.; Landis, C. R.; Weinhold, F. N., http://nbo6.chem.wisc.edu/ 2013. 